\title{
Do Prices Determine Vertical Integration? Evidence from Trade Policy*
}

\author{
Laura Alfaro \\ Harvard Business School and NBER
}

\author{
Paola Conconi \\ Université Libre de Bruxelles (ECARES) and CEPR
}

\author{
Harald Fadinger \\ University of Vienna
}

\author{
Andrew F. Newman \\ Boston University and CEPR
}

October 2012

\begin{abstract}
This paper shows that product prices determine organizational design by studying how trade policy affects vertical integration. Property rights theory asserts that firm boundaries are chosen by stakeholders to mediate organizational goals (e.g., profits) and private benefits (e.g., operating in preferred ways). We present an incomplete-contracts model in which vertical integration raises output at the expense of lower private benefits. A key implication is that higher prices should result in more integration, since the organizational goal becomes relatively more valuable than private benefits. Trade policy provides a source of exogenous price variation to test this proposition: higher tariffs should lead to more vertical integration; moreover, ownership structures should be more alike across countries with similar levels of protection. To assess the evidence, we construct firm-level indices of vertical integration for a large set of countries and industries and exploit cross-section and time-series variation in import tariffs to examine the impact of prices on organizational choices. Our empirical results provide strong support for the predictions of the model.
\end{abstract}

JEL classifications: D2, L2,

Keywords: theory of the firm, incomplete contracts, vertical integration, product prices.

\footnotetext{
*Some of the material in this paper appeared in "Trade Policies and Firm Boundaries," CEPR DP 7899, which it supersedes. We wish to thank for their comments participants at the the 2010 AEA conference in Atlanta, the 2010 MWIEG meeting at Northwestern University, the 2010 Hitotsubashi COE Conference on International Trade and FDI, the 2011 CEPR ERWIT conference, the 2012 International Research Conference at Harvard Business School, the 2012 FREIT conference in Ljubljana, the 2012 NBER Summer Institute on Development and Productivity, and seminar participants at ETH Zurich, Université Catholique de Louvain (CORE), University of Munich, University of Innsbruck, K.U. Leuven, University of Vienna, London School of Economics, and MIT. We are particularly grateful to Daron Acemoglu, Robby Akerlof, Nick Bloom, Holger Breinlich, Bob Gibbons, Gene Grossman, Maria Guadalupe, Oleg Itskhoki, Margaret Mcmillan, Emanuel Ornelas, Ralph Ossa, Steve Redding, Raffaella Sadun, John Van Reenen, and Chris Woodruff for their valuable suggestions. Research funding from the FNRS and the European Commission (PEGGED collaborative project) is gratefully acknowledged by Paola Conconi. We thank Francisco Pino, Andrea Colombo and Qiang Wang for excellent research assistance.
} 


\section{Introduction}

What determines firm boundaries? How many links in a supply chain are to be integrated into a single firm? Answering these questions has been a fundamental concern of organization economics since Coase's (1937)'s seminal paper. In the modern theory of the firm, ownership structure affects incentives and therefore the productivity of an individual firm (Grossman and Hart 1986, Hart and Moore, 1990, Holmström and Milgrom 1991). More recently, these firmlevel effects have been shown theoretically to have implications for industry performance as well (Legros and Newman, 2012). Thus, an understanding of the determinants of vertical integration has implications far beyond the boundaries of organizational economics.

In incomplete contracts models, property rights over assets, which define firm boundaries and determine allocations of control over production decisions, are chosen to mediate how a firm's stakeholders trade off collective goals and private interests. Recent theoretical work has embedded these models into market settings to study how firms' boundary choices are affected by market conditions. In particular, market thickness, demand elasticities, and terms of trade in supplier markets may have an impact on firms' vertical integration decisions (e.g., McLaren, 2000; Grossman and Helpman, 2002; Legros and Newman, 2008, 2012). So far, evidence on the importance of these factors is sparse.

In this paper, we exploit variation in the degree of trade protection faced by firms to show that market conditions, particularly the level of product prices, affect vertical integration: higher prices imply more integration. Our investigation is guided by theory that predicts such an association, based on the idea that integrating an enterprise enhances productivity, but also imposes higher private costs on the managers who determine its ownership structure (e.g., Hart and Holmström, 2010; Legros and Newman, 2012). Product price enters the tradeoff because it directly affects the organization's profit objective, but has a negligible impact on the costs. As the price rises, the tradeoff is resolved in favor of more integration, since the organizational goal becomes relatively more valuable than private goals.

The straightforward empirical strategy to verify whether product prices and the degree of vertical integration are positively correlated, as suggested by this organizational theory, would be to regress some measure of vertical integration on industry prices. The main difficulty with this approach is that it would not allow us to clearly distinguish the organizational theory, in which higher prices lead to more integration, from models that predict the same positive correlation, but with causality going the opposite way. According to these "market-foreclosure" theories, in imperfectly competitive industries, firms may integrate with their suppliers to reduce competition with their rivals, thus pushing product prices higher. ${ }^{1}$ Testing whether product prices affect organization design thus requires an exogenous source of price variation.

In this respect, trade policy provides an ideal proving ground: the degree of trade protection

\footnotetext{
${ }^{1}$ See Salinger (1988) for an early contribution and Rey and Tirole (2007) for a survey.
} 
obviously affects equilibrium prices, but is unlikely to be influenced by firms' vertical integration decisions. The main prediction of our theory is that import tariffs, by increasing product prices in the domestic market, should lead to more vertical integration. This effect should be stronger for firms that operate only in the domestic market, since their organizational objectives depend exclusively on domestic prices; in contrast, exporters and multinational firms should be less affected, since their decisions also depend on prices in foreign markets. Moreover, the effect of tariffs on organization should be stronger in sectors where product prices are more sensitive to tariffs.

We examine the organizational effects of applied Most-Favored-Nation (MFN) tariffs. Under the MFN principle set out in the first article of the General Agreement on Tariffs and Trade (GATT), member countries agree not to discriminate between their trading partners (with the exception of regional trading partners and developing countries). MFN tariffs are the results of long-term multilateral trade negotiations, in which GATT/WTO members commit not to exceed certain tariff rates; if a member raises its MFN tariffs above the agreed bound level, other members can take it to dispute settlement. As a result, MFN tariffs are less responsive to domestic political pressure than administrative measures for the regulation of imports, such as anti-dumping and countervailing duties (e.g., Finger et al, 1982). ${ }^{2}$ In our main empirical analysis, we exploit cross-sectoral and cross-country variation in MFN tariffs applied in 2004 to study the impact of product prices on firm-level vertical integration. ${ }^{3}$ Reverse causality is unlikely to be a concern for our analysis, since the MFN tariffs faced by firms in 2004 were determined during the Uruguay Round of multilateral trade negotiations (1986-1994). ${ }^{4}$

To study firm organization across a wide range of countries, we use the WorldBase dataset from Dun and Bradstreet (D\&B), which contains both listed and unlisted plant-level observations for a large set of countries and territories. For each plant, the dataset includes information about its different production activities at the 4-digit SIC level, as well as about ownership (e.g., its domestic or global parent). To measure vertical integration, we follow the methodology developed by Fan and Lang (2000) and Acemoglu, Johnson and Mitton (2009). By combining information on firms' production activities with input-output tables, we construct firm-level vertical integration indices that measure the fraction of inputs used in the production of a firm's final good that can be produced in house. In our main empirical analysis, we focus on firms that are located in only one country. These provide a cleaner analysis of the effects of tariffs

\footnotetext{
${ }^{2}$ This is one of the reasons why papers that empirically test the impact on lobbying on trade policy use data on non-tariff barriers (NTB) rather than MFN tariffs.

${ }^{3} \mathrm{MFN}$ tariffs vary substantially both across sectors within countries and across countries for a given sector. For example, U.S. manufacturing tariffs in 2004 averaged 2.4 percent, with a minimum of zero and a maximum of 350 percent. As an example of cross-country variation, for a sector like SIC 3631 (Household Cooking Equipment), MFN tariffs varied between zero and 29 percent, with an average of 3.15 percent.

${ }^{4}$ Since the Uruguay Round, GATT/WTO members have not changed their MFN tariff bounds. Applied rates have changed little over time, since they coincide with the bound rates for most countries and sectors (see www.wto.org).
} 
on firms' ownership structure, since their vertical integration decisions should depend only on domestic prices. In the case of multinational corporations, on the other hand, it is harder to identify the relevant prices and tariffs. Moreover, focusing on national firms avoids issues having to do with the strategic behavior of multinationals across markets (e.g., transfer pricing, tariff jumping, export platforms).

Our empirical analysis provides strong support for the predictions of the model. We find that, the higher is the MFN tariff applied by a country on the imports of a given product, the more vertically integrated are the firms producing that product in that country. The effect is larger when we would expect organizational decisions to be more responsive to import tariffs, i.e., for firms that only serve the domestic market and in sectors in which MFN tariffs have a larger impact on domestic prices. Our results are robust to constructing vertical integration indices in different ways, including standard determinants of firm boundaries, using alternative econometric methodologies, and focusing on different samples of firms and countries.

In terms of magnitude, in our baseline estimation, a 100 percent tariff increase leads to a 2.15 percent increase in the vertical integration index, implying that increasing tariffs from 1 percent to their mean level of around 5 percent would increase vertical integration by more than 8 percent. Notice, however, that our estimates should be interpreted as a lower bound on the impact of prices on vertical integration, since domestic prices do not fully adjust to tariff changes. ${ }^{5}$ The true impact is likely to be substantially larger. ${ }^{6}$

In our theory, in which firms are price takers, import tariffs affect firms' organization only through their effect on domestic prices. However, tariffs may also have an impact on the degree of competition faced by domestic firms, which may also shape vertical integration decisions (Aghion, Griffith, and Howitt, 2006). To isolate the effect of product prices, we restrict our analysis to highly competitive sectors, in which tariffs will have little or no effect on the degree of competition, obtaining even stronger results.

To establish a causal link between tariffs and vertical integration, we also show that our results are not driven by omitted variables, which might be correlated with both vertical integration decisions and MFN tariffs. First, large firms or concentrated industries could be more effective at lobbying for protection and may also be more vertically integrated. Second, tariffs that exporters face in other markers or tariffs on imported inputs are likely to be correlated with tariffs on final products and may also affect firms' organization decisions. Our results are unaffected when including these controls in our analysis.

An alternative strategy to verify the impact of trade policy on firm boundaries is to focus

\footnotetext{
${ }^{5}$ In the case of ad valorem tariffs, domestic prices will vary by less than the tariff. Tariff pass-through may also be attenuated if firms have market power and adjust their markups. Finally, to the extend that a country is large, i.e., can affect world prices, imposing a tariff will have an impact on the world price and the elasticity of domestic prices with respect to tariffs will also be less than one.

${ }^{6}$ To get a sense of the magnitude of the effects of prices on organization, one would ideally instrument prices with MFN tariffs; however, this would require comparable cross country data on domestic prices, which are very difficult to obtain (see Bradford, 2003).
} 
on trade liberalization reforms - major unilateral or multilateral liberalization episodes, or the creation of regional trade agreements - thus exploiting time variation in the degree of protectionism faced by firms. The challenge with implementing this strategy is data availability, since we can only construct firm-level vertical integration measures for recent years, during which there have been few trade liberalization reforms. ${ }^{7}$ The only major trade liberalization episode that has occurred in recent years is arguably the entry of China into the WTO in 2001: to be accepted as a WTO member, China had to undertake a series of important tariff reductions so as to substantially expand market access for goods from foreign countries. We examine the organizational effects of these trade policy changes, comparing the ownership structure of Chinese firms before and after WTO accession (in 1999 and 2007). Consistent with the predictions of our theoretical model, we find that firm-level vertical integration has fallen more in sectors that have experienced larger tariff cuts.

We also study the effect of trade policy on the degree of organizational convergence across countries. Our theory suggests that countries with similar domestic price levels should have firms with similar ownership structures. In line with this prediction, we show that differences in vertical integration across countries are significantly larger in sectors in which differences in MFN tariffs (and therefore differences in domestic prices) are larger. Moreover, we find that differences in vertical integration indices are smaller for country pairs engaged in regional trade agreements. ${ }^{8}$ This effect is stronger for customs unions, which impose common external tariffs vis-à-vis non-members and should thus be characterized by stronger price convergence.

Our paper contributes to a recent stream of empirical work that examines the determinants of firms' vertical integration decisions (i.e., firm boundaries/ownership structure). Some studies focus on single industries. ${ }^{9}$ In this literature, Hortaçsu and Syverson (2007) focus on the U.S. cement industry and examine whether vertical integration leads to higher prices. In contrast with the predictions of market foreclosure theories, they find that prices fall when markets become more integrated. The focus of our analysis is on the opposite direction of causality, i.e., the impact of product prices on vertical integration decisions. Other studies focus on a single country. For example, Acemoglu, Aghion, Griffith and Zilibotti (2010) use data on British manufacturing plants to study the relationship between vertical integration and rates of innovation. Aghion, Griffith and Howitt (2006) investigate whether the propensity for firms to vertically integrate varies systematically with the extent of competition in the product market. In terms of data

\footnotetext{
${ }^{7}$ Important trade liberalization episodes, such as the conclusion of the Uruguay Round of GATT/WTO trade negotiations, the North American Free Trade Agreement (NAFTA), or the free trade agreements between Eastern European countries and the European Community, all occurred in the early or mid-nineties.

${ }^{8}$ As mentioned above, under Article I of the GATT, countries have to apply the same MFN tariff to all trading partners. Preferential treatment can only be granted to partners in regional trade agreements (Article XXIV of the GATT) or to developing countries (in the context of the Generalized System of Preferences (GSP) allowed by the Enabling Clause).

${ }^{9}$ These include the seminal papers by Stuckey (1983) on integration between aluminium refineries and bauxite mines and Joskow (1987) on ownership arrangements in electricity generating plants, as well as the more recent studies by Baker and Hubbard $(2003,2004)$ on the trucking industry, Woodruff (2002) on Mexican footwear.
} 
and methodology, our analysis is closely related to the paper by Acemoglu, Johnson and Mitton (2009), who study the determinants of vertical integration using a cross-section of D\&B data for 93 countries, focusing on the role of financial development and contracting costs. Ours is the first paper to examine how product prices affect integration decisions.

A related stream of the literature has studied other aspects of organization, such as management practices or the degree of delegation within firms. Bloom and Van Reenen (2007) study managerial practices in medium-sized manufacturing firms in the US and Europe (France, Germany and the UK), finding that best practices are strongly associated with superior firm performance. Bloom, Sadun and Van Reenen (2010), using survey data on medium-sized manufacturing firms across a dozen countries, find that greater product market competition increases decentralization. Bloom, Sadun and Van Reenen (2012) collect data on the decentralization of investment, hiring, production, and sales decisions for almost 4,000 firms in the United States, Europe, and Asia, finding that firms headquartered in high trust regions are more likely to decentralize. Guadalupe and Wulf (2012) show that the 1989 Canada-United States Free Trade Agreement (CUSFTA) led large U.S. firms to flatten their hierarchies.

Finally, various papers examine whether goods are sold within or across firm boundaries in the global economy (e.g., Antras, 2003; Nunn, 2007). This literature studies organizational choices of firms across countries, focusing mostly on the role of contract enforcement and relationshipspecific investments. Our approach is fundamentally different: our goal is to verify whether product prices affect vertical integration decisions; for this reason, we focus our attention to organizational choices of firms in domestic markets.

The rest of the paper is organized as follows. Section 2 presents a theoretical framework to guide our empirical analysis. Section 3 describes our data. Section 4 presents our main results on tariffs and vertical integration, including both cross-sectional and time series evidence. Section 5 analyzes the impact of trade policy on the degree of cross-country organizational convergence. The last section concludes.

\section{Theoretical framework}

We describe a simple theoretical framework to guide our empirical analysis. This is meant to capture the features of a class of organizational models in which vertical integration decisions mediate how a firm's stakeholders trade off their pecuniary stake in the organizational goal against their private interests.

We adapt the model by Legros and Newman (2012), in which managers of different production units trade off the benefits of coordinating production decisions against the cost of accommodating to common ways of doing things. A feature of this model is that vertical integration generates more output than non-integration, but imposes a fixed cost on managers, who lose the ability to operate in their preferred ways. As a result, the price of output helps determine 
firm boundary decisions: at low prices, managers are more concerned with their private benefits and remain non-integrated; at higher prices, output is more valuable, so managers prefer vertical integration. Since tariffs affect output prices, they also influence firm boundaries. For simplicity, in the version of the model described below, there are only two inputs of production, so vertical integration is a dichotomous choice. The analysis can be generalized to a setting with $N$ inputs, in which stakeholders choose the optimal degree of integration.

\section{Setup}

We consider a perfectly competitive industry populated by "organizational" rather than "neoclassical" firms. Demand is given by $D(p)$ (consumers have quasi-linear utility), where $p$ is the industry price. Production of the good requires the cooperation of two types of input suppliers, denoted $A$ and $B$. $B$ suppliers generate no value without being matched with an $A$; $A$ suppliers can either match with a $B$ or engage in stand-alone production of a numeraire good, the price of which is normalized to 1 . Many interpretations of the $A$ and $B$ firms are possible. For example, $A$ suppliers may represent light assembly plants or basic inputs, such as energy, or various business services (e.g., IT, retailing, logistics) that can be used to produce basic consumer goods or combined with other inputs ( $B$ suppliers) to produce more complex goods.

All goods are sold under conditions of perfect competition. There is a continuum of each type of supplier, with a measure $n<1$ of $B$ 's, and a unit measure of $A$ 's. Since the aggregate supply of $A$ 's exceeds that of the $B$ 's, a positive amount of numeraire is produced in equilibrium.

An equilibrium in the supplier market consists of a stable match between each $B$ supplier and an $A$ supplier: given the surplus allocation among all the suppliers, no $(A, B)$ pair can form an enterprise that generates higher than equilibrium payoffs for each partner. All $A$ suppliers are equally productive when matched with one of the $B$ 's. A stand-alone $A$ produces $\alpha$ units of the numeraire good. Since the price of the numeraire is equal to unity, this also pins down the equilibrium payoff for all $A$ 's. ${ }^{10}$

\section{Individual enterprises}

We adopt a simple model of firm boundaries based on a tradeoff between the pecuniary benefits of coordinating production decisions and managers' private benefits of operating in their preferred ways. As in Grossman and Hart (1986), integration and non-integration both suffer from incentive costs. However, in the framework described below, these emerge in a particularly tractable way: integration, though more productive because of better coordination, imposes a fixed cost on managers, by forcing them to adopt a common "compromise" solution.

\footnotetext{
${ }^{10}$ See Conconi, Legros and Newman (2012) for a more general setup, in which the outside option of $A$ suppliers is endogenously determined
} 
Once an enterprise composed of an $A$ and a $B$ has formed in the supplier market, a noncontractible decision (e.g., choosing compatible technologies, deciding on marketing campaigns) about the way in which production is to be carried out must be made by each unit. Denote the $A$ and $B$ decisions respectively by $a \in[0,1]$ and $b \in[0,1]$. Successful production requires coordination between the two suppliers. More precisely, the enterprise will succeed with a probability $1-(a-b)^{2}$, in which case it generates $R>0$ units of output; otherwise it fails, yielding 0 . Output realizations are independent across enterprises ( $A-B$ pairs). We allow $R$ to vary across enterprises, so it can be interpreted as some measure of enterprise-specific productivity.

Managers are risk-neutral and bear a private cost of implementing the decision made by their units. The $A$ manager's utility is $y_{A}-(1-a)^{2}$, the $B$ manager's is $y_{B}-b^{2}$, where $y_{A}, y_{B} \geq 0$ are their respective incomes and $(1-a)^{2}$ and $b^{2}$ are their costs. Though both managers of the $A$ and $B$ units enjoy monetary returns, they view their operations differently: $A$ 's most preferred action is 1 , while $B$ 's is 0 . For instance, a standardized production line could be convenient for $A$ suppliers, but may not fit the specific design needs of the $B$ suppliers. Because managers' primary function is to implement decisions and convince their workforces to comply, they bear the cost of decisions even if they don't make them.

Assignment of decision rights via possible sale of assets is the organizational design problem in the model. Managers may remain non-integrated and retain control over their respective decisions. Or they can choose to integrate into a single firm by engaging a headquarters (HQ), transferring to it, in exchange for an acquisition fee, a share of the realized revenue and the power to decide $a$ and $b$. HQ is motivated only by monetary considerations (the desire to maximize the integrated firm's income) and incurs no costs for operating in a particular way.

Before production, $B$ managers match with $A$ managers and sign contracts specifying an ownership structure and payment scheme. For simplicity, we take the payment scheme to be a fixed payment $T$ from $B$ to $A$. Because $A$ 's are in excess supply, they must all receive $\alpha$ in equilibrium. Thus $T$ will just cover $A$ 's anticipated private cost of production together with the opportunity cost $\alpha .^{11}$

For each match $(A, B)$, total revenue in event of success is given by the number of units produced, $R$, times the product market price, $p$, which is taken as given and correctly anticipated when managers and HQs sign the contracts and make their decisions. After contracts are signed, managers and HQs make their production decisions, output is realized, product is sold, and revenue shares are distributed.

\footnotetext{
${ }^{11}$ In general, $B$ may prefer to give $A$ a positive contingent share of revenue. This complicates notation but does not change any qualitative conclusion regarding the dependence of integration on price (see Legros and Newman, 2012).
} 


\section{Integration}

HQs are elastically supplied at a cost normalized to zero. After paying its acquisition fee and receiving its compensating share of revenue, an HQ's payoff is proportional to $\left(1-(a-b)^{2}\right) R p .{ }^{12}$ HQs decide both $a$ and $b$, and since their incentive is to maximize he integrated firms' expected revenue, they choose $a=b$. Among the choices in which $a=b$, the Pareto-dominant one is that in which $a=b=1 / 2$, which minimizes the total cost of the $A$ and $B$ managers. We assume HQs implement this choice. The private cost to each manager is then $\frac{1}{4}$, and the payoffs to the $A$ and $B$ managers are equal to $\alpha$ and $R p-\alpha-\frac{1}{2}$, respectively (thus $T=\alpha+\frac{1}{4}$ ).

\section{Non-integration}

Under non-integration, managers retain control of their respective activities. The decisions chosen are the (unique) Nash equilibrium of the game with payoffs $T-(1-a)^{2}$ for $A$, who chooses $a$, and $\left(1-(a-b)^{2}\right) R p-b^{2}-T$ for $B$, who chooses $b$. Nash decisions are $a=1$ and $b=R p /(1+R p)$, with resulting expected output $1-\frac{1}{(1+R p)^{2}}$. Notice that output increases with price: as $p$ becomes larger, the revenue motive becomes more important for $B$ managers, pushing them to better coordinate with their $A$ partners. The equilibrium transfer from $B$ to $A$ under non-integration is $T=\alpha$; the payoffs are $\alpha$ for $A$ 's and $\frac{(R p)^{2}}{1+R p}-\alpha$ for $B$ 's.

\section{Choice of ownership structure}

To determine managers' choice of firm boundaries, we must compare their payoffs under integration and non-integration. Notice that $A$ suppliers obtain $\alpha$ in both cases, so they are indifferent about the organizational choice. $B$ suppliers obtain a higher payoff under integration if and only if $R p-\frac{1}{2}>\frac{(R p)^{2}}{1+R p}$ or $p>1 / R$. Thus managers' organizational choices depend on product prices. At low prices, revenues are small enough that integration's better output performance is not valuable enough to the $B$ to be worth the private cost he would have to bear; thus, $B$ opts for the "quiet life" of non-integration, wherein both profits and costs are low. At higher prices, the $B$ manager's revenue motive now makes higher output and therefore coordination more valuable. Coordinating under non-integration would entail large and costly concessions from $B$ to $A$, who chooses $a=1$ independently of the price; the compromise choice $a=b=\frac{1}{2}$, is now preferable, so $B$ chooses to integrate. Clearly, the price at which an enterprise integrates is lower when its productivity $R$ is higher. This is because the cost of integrating is independent of productivity, while the benefit in terms of increased output (therefore profit) is larger when the enterprise is more productive.

\footnotetext{
${ }^{12}$ The size of HQ's share is indeterminate and could be pinned down in many ways not modeled here; all that matters for our purposes is that it is positive. In fact, an HQ with control over $a$ and $b$ would never accept a zero revenue share: she could always renegotiate to something positive. See Legros and Newman (2012).
} 


\section{Product market equilibrium and the OAS curve}

An industry equilibrium entails clearing supplier and product markets. We have already characterized the supplier market: every $A$ receives $\alpha$, either by producing by herself $\alpha$ units of the numeraire, or by matching with with a $B$ to produce the industry good for a net payoff of $\alpha$.

In the product market, the large number of enterprises implies that with probability one the supply is equal to the expected value of output given $p$; equilibrium requires that this price adjusts so that demand equals supply.

To derive industry supply, suppose $R$ is distributed in the population according to some continuous c.d.f. $G(R)$ with mean 1 and support $[\underline{R}, \bar{R}]$. Since all enterprises with $R<1 / p$ remain non-integrated, and the remaining ones integrate, total supply at price $p \in[1 / \bar{R}, 1 / \underline{R}]$ is (recall that $n$ is the measure of $B$ suppliers)

$$
S(p)=n\left[\int_{\underline{R}}^{1 / p} R\left(1-\left(\frac{1}{1+R p}\right)^{2}\right) d G(R)+\int_{1 / p}^{\bar{R}} R d G(R)\right] .
$$

If $p<1 / \bar{R}$, supply is $n \int_{\underline{R}}^{\bar{R}} R\left(1-\left(\frac{1}{1+R p}\right)^{2}\right) d G(R)$; if $p>1 / \underline{R}$, it is $n$.

Figure 1: The OAS and market equilibrium

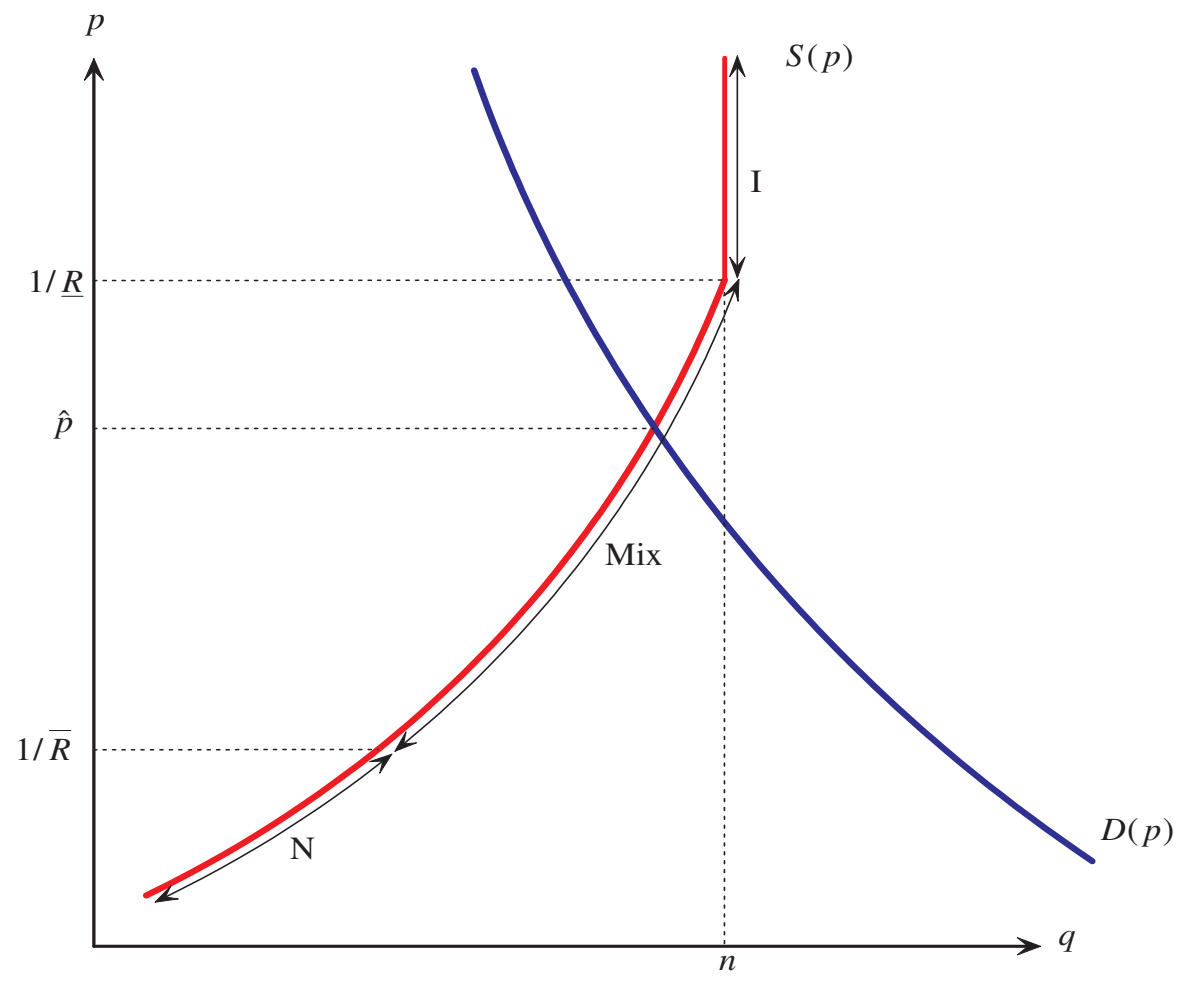

Figure 1 depicts the Organizationally Augmented Supply (OAS) curve, which incorporates the ownership structure decisions of the industry's enterprises as well as the usual price-quantity 
relationship. It also illustrates the price regions indicated by the black arrows in which enterprises are all non-integrated $(\mathbf{N})$, all integrated $(\mathbf{I})$, and the middle range in which only the more productive ones integrate (Mix). When $p<1 / \bar{R}$, the industry is entirely non-integrated, but supply increases with price, since non-integration expected output increases. As price rises above $1 / \bar{R}$, the most productive enterprises integrate, producing more than they would under non-integration; those that remain non-integrated also produce more, so that industry output rises further. Once $p$ reaches $1 / \underline{R}$, all firms are integrated and industry supply is fixed at $n$ (the mean $R$ being 1 ) for prices higher than that threshold. In the absence of trade, the equilibrium price $\hat{p}$ equates domestic supply and demand.

Observe that, for a given market price $p$, more productive enterprises (those with higher $R$ ) are more likely to be vertically integrated. The degree of integration of the industry (i.e., the fraction $1-G(1 / \hat{p})$ of firms that integrate) is therefore a nondecreasing function of the equilibrium price, strictly increasing on $[\underline{R}, \bar{R}] .{ }^{13}$

\section{Trade policy and firms' organization}

The key prediction of this theoretical framework is that higher prices on final goods should lead firms to be more vertically integrated. As discussed in the introduction, testing this prediction requires an exogenous source of price variation. Trade policy provides an ideal proving ground: the degree of trade protection obviously affects product prices, but is unlikely to be affected by firms' boundary choices.

Suppose now that the industry is import competing, i.e., at the world price $P$ for the good, $D(P)>S(P)$, so some of the domestic demand must be satisfied by imports. Suppose further that the country in which our industry resides is small, i.e., the world price $P$ is unaffected by its trade policy.

Consider the introduction of an ad valorem tariff $t$, which drives a wedge between the world price and the domestic price, $p=P(1+t)$. By increasing the domestic price, the tariff increases managers' incentives to vertically integrate, since the organizational goal becomes relatively more important than their private goals.

Trade policy affects ownership structures through its impact on product prices. In particular, an increase in $t$ leads to an increase in the domestic price of the good; an enterprise with productivity $R$ will choose integration if the new price exceeds $1 / R$. Figure 2 depicts the OAS curve of the industry. In this example, absent any tariff, the domestic price would be equal to the world price $P$, and all firms in the domestic industry would be non-integrated. Now consider a tariff $t$ that raises the domestic price to $p^{\prime}=P(1+t)$, which lies between $1 / \bar{R}$ and $1 / \underline{R}$. At this price, more productive enterprises (with $R>1 / p^{\prime}$ ) will integrate and less productive ones

\footnotetext{
${ }^{13} R$ can also capture exogenous differences in scale; then, for a given market price $p$, larger firms should be vertically integrated. If scale is endogenous, more productive firms will both be larger and more integrated (Legros and Newman, 2012).
} 
will remain non-integrated. Clearly, a lower tariff would lead to fewer integrated firms, a higher one to more. Integration therefore increases with the tariff level.

Figure 2: Firm organization in the presence of a tariff

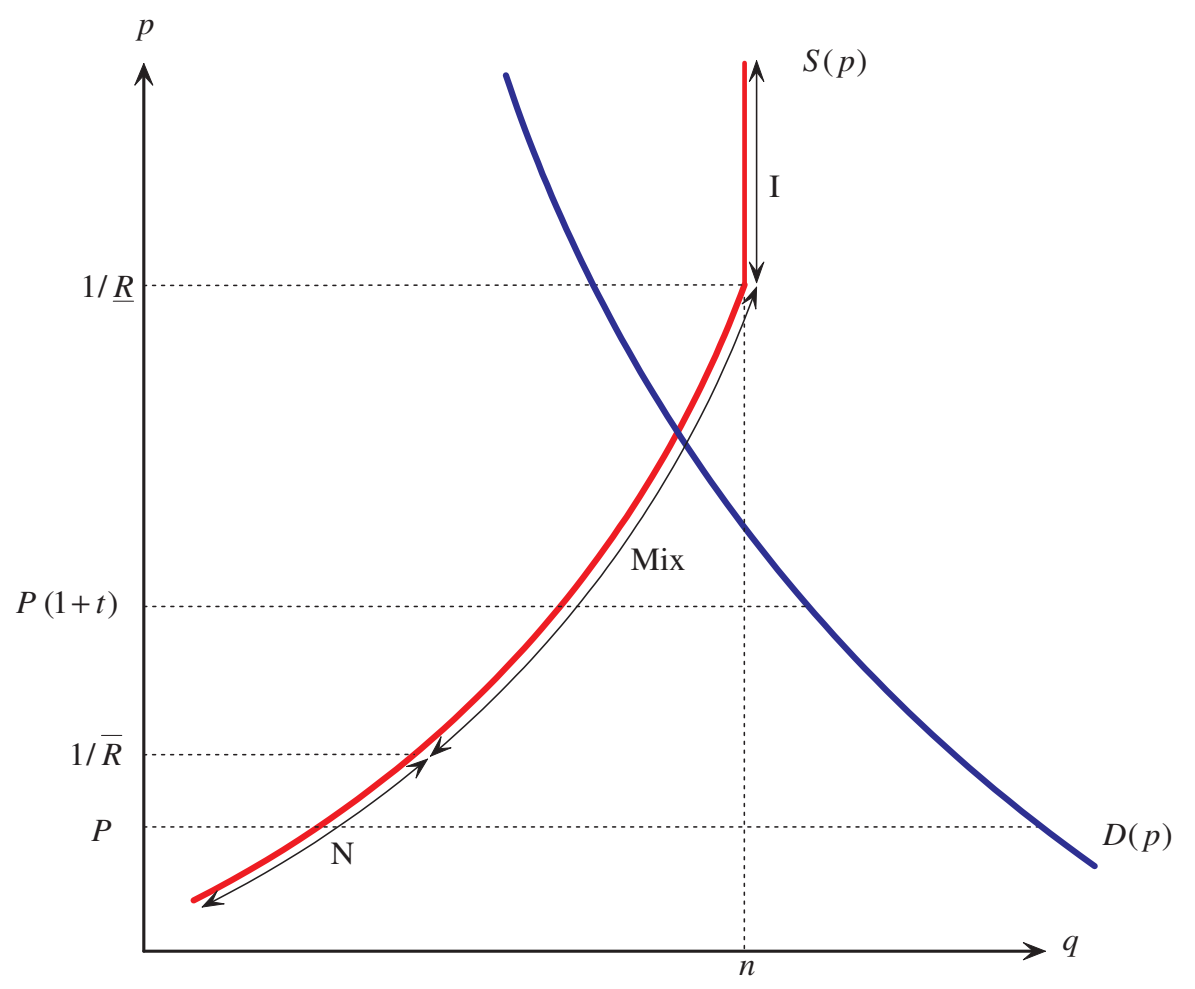

The impact of the import tariff on integration decisions should be stronger for firms that only serve the domestic market, since the organization's objective (profit) depends only on the domestic price; the effect should be weaker for exporting firms (and multinationals), since their profits also depend on product prices in foreign markets.

The impact of trade policy on the degree of vertical integration should also depend on the extent to which import tariffs affect domestic prices. The higher the share of imports that are subject to the tariff, the larger the effect of tariffs on organization. Thus membership in regional trade agreements (in which member countries freely trade with each other) and differences across countries and sectors in the share of imports that are exempt from tariffs provide an additional source of variation to test our hypothesis.

This framework can also be used to examine how trade policy affects the degree of organizational convergence across countries. In effect, the law of one price implies the "law of one organization": for a pair of countries $c$ and $c^{\prime}$, the difference in degree of integration within a sector will depend on the difference in their applied tariffs: the closer are $t^{c}$ and $t^{c^{\prime}}$, the smaller the difference between $p^{c}$ and $p^{c^{\prime}}$ and the more similar firms' ownership structures within the industry. In regional trade agreements, prices should tend to converge across member countries. 
In particular, customs unions, in which members adopt common external tariffs, should have more similar ownership structures than free trade areas, in which differences in external tariffs, together with problems in implementing rules of origin, reduce the extent of price convergence.

For the purpose of our empirical analysis, the main predictions of our theoretical framework can be summarized as follows:

1. Higher import tariffs on final goods should lead domestic firms to be more vertically integrated.

2. The effect of tariffs on integration should be larger for firms selling only in the domestic market.

3. The effect of tariffs on integration should be larger in sectors in which a smaller fraction of imports are exempt from the tariff.

4. Country pairs should have more similar ownership structures in sectors where they have similar levels of protection; regional trade agreements, especially customs unions, should display similar ownership structures among members.

\section{Dataset and variables}

\subsection{The WorldBase database}

Increasingly, researchers use multi-country firm-level data to study issues of organization economics (e.g., Bloom and Van Reenen, 2007; Bloom, Sadun and Van Reenen, 2012). However, cross-country empirical investigations at the firm level are notoriously challenging due to both the lack of data and the difficulty of comparing the few high quality time-series datasets that are available (mostly in rich countries). The reason for the data constraint is simple: economic censuses of firms are infrequently collected due to high costs and institutional restrictions, especially in poor countries. No institution has the capacity or resources to collect census data for a wide range of countries and periods. This is why researchers have to use other sources, such as business "compilations" (registries, tax sources) or surveys.

To measure vertical integration, we use data for 2004 from Dun \& Bradstreet's WorldBase, a database of public and private plant-level observations in more than 200 countries and territories. ${ }^{14}$ WorldBase contains information on public and private companies. The unit of observation

\footnotetext{
${ }^{14}$ WorldBase is the core database with which D\&B populates its commercial data products, including Who Owns Whom ${ }^{\mathrm{TM}}$, Risk Management Solutions ${ }^{\mathrm{TM}}$, Sales \& Marketing Solutions ${ }^{\mathrm{TM}}$, and Supply Management Solutions ${ }^{\mathrm{TM}}$. These products provide information about the "activities, decision makers, finances, operations and markets" of the clients' potential customers, competitors and suppliers. The dataset is not publicly available but was released to us by Dun and Bradstreet. For more information see: http://www.dnb.com/us/about/db_database/dnbinfoquality.html.
} 
in WorldBase is the establishment/plant. With a full sample, plants belonging to the same firm can be linked via information on domestic and global parents using the DUNS numbers. ${ }^{15}$

The WorldBase dataset has been used extensively in the literature. Early uses of D\&B data include Caves' (1975) analysis of size and diversification patterns between Canadian and U.S. plants. More recent uses include Harrison, Love, and McMillian (2004), Black and Strahan (2002), Alfaro and Charlton (2009), and Acemoglu, Johnson and Mitton (2009). One of the advantages of WorldBase compared to other international datasets is that it is compiled from a large number of sources (e.g., partner firms, telephone directory records, websites, selfregistration). Admittedly, sample coverage may vary across countries, but this problem can be mitigated by focusing on manufacturing firms above a size threshold of twenty employees (see discussion below). ${ }^{16}$

\subsection{The sample}

Our main sample is based on the 2004 WorldBase dataset (for the analysis of China's accession to the WTO, we use data from 1999 and 2007). The unit of observation in WorldBase is the establishment (a single physical location at which business is conducted or services or industrial operations are performed) rather than the firm (one or more domestic establishments under common ownership or control). Establishments, which we also refer to as plants, have their own addresses, business names, and managers, but might be partly or wholly owned by other firms. As mentioned above, plants can be linked via information on domestic and global parents using DUNS numbers.

We use different categories of data recorded by WorldBase records for each establishment:

Industry information: the 4-digit SIC code of the primary industry in which each establishment operates, and for most countries, the SIC codes of as many as five secondary industries, listed in descending order of importance.

Ownership information: information about the firms' family members (number of family members, its domestic parent and its global parent). ${ }^{17}$

\footnotetext{
${ }^{15}$ D\&B uses the United States Government Department of Commerce, Office of Management and Budget, Standard Industrial Classification Manual 1987 edition to classify business establishments. The Data Universal Numbering System — the D\&B DUNS Number — introduced in 1963 to identify businesses numerically for dataprocessing purposes, supports the linking of plants and firms across countries and tracking of plants' histories including name changes.

${ }^{16}$ Other datasets use different methodologies in different countries. For example, the Amadeus dataset, provided like Orbis by Bureau Van Dijk, uses data from the national public body in charge of collecting the annual accounts in some countries (e.g., the UK) and collects it directly from firms in other countries (most of Eastern Europe). Because of different disclosure requirements, the amount and type of information also varies among countries. See Alfaro and Charlton (2009) for a more detailed discussion of the WorldBase data and comparisons with other data sources.

${ }^{17} \mathrm{D} \& \mathrm{~B}$ also provides information about the firm's status (joint-venture, corporation, partnership) and its position in the hierarchy (branch, division, headquarters).
} 
Location information: country, state, city, and street address of each family member (used to link establishments within a family to the relevant tariff data).

Basic operational information: sales and employment.

Information on the firm's trade status (exporting/non-exporting).

We exclude countries and territories with fewer than 80 observations and those for which the World Bank provides no data. We further restricted the sample to Word Trade Organization (WTO) members for which we have data on tariffs/regional trading arrangements (see the discussion below).

We focus on manufacturing firms (i.e., firms with a primary SIC code between 2000 and 3999), which best fit our theory of vertical integration and for which data on MFN tariffs are widely available. We exclude firms that do not report their primary activity, government/public sector firms, firms in the service sector (for which we have no tariff data) or agriculture (due to the existence of many non-tariff barriers), and firms producing primary commodities (i.e., mining and oil and gas extraction).

We further exclude firms with less than 20 employees, as our theory does not apply to selfemployment or small firms with little prospect of vertical integration (see also Acemoglu, Aghion, Griffith and Zilibotti, 2010). Restricting the analysis to firms with more than 20 employees also enables us to correct for possible differences in the the collection of small firms data across countries (see Klapper, Laeven, and Rajan, 2006).

In our main sample, we focus on firms that are located only in one country. This provides a cleaner setting to verify the predictions of our theoretical model, since the degree of vertical integration of these firms should depend primarily on the price at which they sell their product in their home country. In the case of multinational corporations, on the other hand, it is harder to identify the relevant prices and tariffs. Moreover, focusing on national firms avoids issues having to do with the strategic behavior of multinationals across markets (e.g., transfer pricing, tariff jumping). ${ }^{18}$

Table A-1 in the Appendix lists the countries included in our main sample. ${ }^{19}$ In robustness checks, we restrict the analysis to two subsamples of countries: members of the OECD, and countries for which we have information on at least 1000 plants.

We next describe the construction of firm-level vertical integration indices, and all other variables used in our empirical analysis. Appendix Table A-2 presents summary statistics for all variables.

\footnotetext{
${ }^{18}$ Multinational corporations are included in the robustness analysis (see Section 4.1.4). In order to link their organizational structure to domestic tariffs, we split them in separate entities — one for each country — and use the primary activity of the respective domestic ultimate to identify the relevant tariff.

${ }^{19}$ Further restrictions were imposed by data availability constraints related to the control variables, as explained in the next subsections.
} 


\subsection{Vertical integration indices}

Constructing measures of vertical integration is highly demanding in terms of data, requiring firm-level information on sales and purchases of inputs by various subsidiaries of a firm. Such data are generally not directly available and, to the best of our knowledge, there is no source for such data for a wide sample of developed and developing countries.

To measure the extent of vertical integration for a given firm, we build on the methodology developed by Fan and Lang (2000) and Acemoglu, Johnson and Mitton (2009). We combine WorldBase information on plant activities and ownership structure with input-output data to determine related industries and construct the vertical integration coefficients $V_{j}^{f, k, c}$ in activity $j$, where $k$ is the primary sector in which firm $f$ in country $c$ is active. ${ }^{20}$

Given the difficulty of finding input-output matrices for all the countries in our dataset, we follow Acemoglu, Johnson and Mitton (2009) in using the U.S. input-output tables to provide a standardized measure of input requirements for each sector. As the authors note, the U.S. input-output tables should be informative about input flows across industries to the extent that these are determined by technology. ${ }^{21}$

The input-output data are from the Bureau of Economic Analysis (BEA), Benchmark IO Tables, which include the make table, use table, and direct and total requirements coefficients tables. We use the Use of Commodities by Industries after Redefinitions 1992 (Producers' Prices) tables. While the BEA employs six-digit input-output industry codes, WorldBase uses the SIC industry classification. The BEA website provides a concordance guide, but it is not a one-toone key. ${ }^{22}$ For codes for which the match was not one-to-one, we randomized between possible matches in order not to overstate vertical linkages. The multiple matching problem, however, is not particularly relevant when looking at plants operating only in the manufacturing sector (for which the key is almost one-to-one).

For every pair of industries, $i, j$, the input-output accounts support calculation of the dollar value of $i$ required to produce a dollar's worth of $j$. We construct the input-output coefficients for each firm $f, I O_{i j}^{f}$ by combining the SIC information for each plant in each firm, the matching codes, and the U.S. input-output information. Here, $I O_{i j}^{f} \equiv I O_{i j} * I_{i j}^{f}$, where $I O_{i j}$ is the input-

\footnotetext{
${ }^{20}$ In Acemoglu, Johnson and Mitton (2009), the sample is restricted to a maximum of the 30,000 largest records per country in the 2002 WorldBase file (a limit imposed by cost constraints). For countries with more than 30,000 observations, they select the 30,000 largest, ranked by annual sales. Having information on the full sample of establishments in WorldBase, we are able to link establishments to firms (see discussion below).

${ }^{21}$ Note that the assumption that the U.S. IO structure carries over to other countries can potentially bias our empirical analysis against finding a significant relationship between vertical integration and prices by introducing measurement error in the dependent variable of our regressions. In addition, using the US input-output tables to construct vertical integration indices for other countries mitigates the possibility that the IO structure and control variables are endogenous. In robustness checks, we verify that our results are unaffected when restricting the analysis to OECD countries, which are more similar to the U.S. in terms of technology and for which using the U.S. IO matrix is thus more appropriate (See Section 4.1.4).

${ }^{22}$ This concordance is available upon request. The BEA matches its six-digit industry codes to 1987 U.S. SIC codes http://www.bea.gov/industry/exe/ndn0017.exe.
} 
output coefficient for the sector pair $i j$, stating the cents of output of sector $i$ required to produce a dollar of $j$, and $I_{i j}^{f} \in\{0,1\}$ is an indicator variable that equals one if and only if firm $f$ owns plants in both sectors $i$ and $j$. A firm that produces $i$ as well as $j$ will be assumed to supply itself with all the $i$ it needs to produce $j$; thus, the higher $I O_{i j}$ for an $i$-producing plant owned by the firm, the more integrated in the production of $j$ the firm will be measured to be. Adding up the input-output coefficients $I O_{i j}^{f}$ for all inputs $i$, gives the firm's degree of vertical integration in $j$.

To illustrate the procedure, consider the following example from Acemoglu, Johnson and Mitton (2009) of a Japanese establishment with, according to WorldBase, one primary activity, automobiles (59.0301), and two secondary activities, automotive stampings (41.0201) and miscellaneous plastic products $(32.0400) .{ }^{23}$ The $I O_{i j}^{f}$ coefficients for this plant are:

\begin{tabular}{cllll} 
& \multicolumn{3}{c}{ Output $(\mathrm{j})$} \\
& & Autos & Stampings & Plastics \\
Input (i) & Statos & 0.0043 & 0.0000 & 0.0000 \\
& Plastics & 0.0405 & 0.0024 & 0.0560 \\
& SUM & 0.1228 & 0.0041 & 0.0560
\end{tabular}

The table is a restriction of the economy-wide IO table to the set of industries in which this establishment is active (i.e., it contains all of the positive $I O_{i j}^{f}$ values). For example, the $I O_{i j}$ coefficient for stampings to autos is 0.078 , indicating that 7.8 cents worth of automotive stampings are required to produce a dollar's worth of autos. Because this plant has the internal capability to produce stampings, we assume it produces itself all the stampings it needs. ${ }^{24}$ The bottom row shows the sum of the $I O_{i j}^{f}$ for each industry. For example, given that 12.3 cents worth of the inputs required to make autos can be produced within this plant, we would say that the degree of vertical integration for this plant is 0.123 .

For firm $f$ in primary sector $k$ located in country $c$, we define the integration index in activity $j$ as

$$
V_{f, k, c}^{j}=\sum_{i} I O_{i j}^{f, k}
$$

the sum of the IO coefficients for each industry in which the firm is active. Our measure of vertical integration is based on the firm's primary activity:

$$
V_{f, k, c}=V_{f, k, c}^{j}, j=k .
$$

\footnotetext{
${ }^{23}$ There is no concern of right censoring in the number of reported activities: only 0.94 percent of establishments with primary activity in a manufacturing sector report the maximum number of five secondary activities.

${ }^{24}$ Many industries have positive $I O_{i j}$ coefficients with themselves; for example, miscellaneous plastic products are required to produce miscellaneous plastic products. Any firm that produces such a product will therefore be measured as at least somewhat vertically integrated.
} 
In the case of multi-plant firms, we link the activities of all plants that report to the same headquarters and consider the main activity of the headquarters as the primary sector. ${ }^{25}$

The approach we follow to identify vertical integration infers a firm's level of vertical integration from information about the goods it produces in each of its establishments and the aggregate input-output relationship among those goods. The advantage of this method is that one need not worry about the value of intra-firm activities being affected by transfer pricing. Another advantage is that using I-O tables avoids the arbitrariness of classification schemes that divide goods into "intermediate" and other categories (Hummels, Ishii, and Yi, 2001).

Summary statistics for firm-level vertical integration are presented in Appendix Table A2, while Table A-3 reports average vertical integration indices by sector (at the 2-digit SIC level). ${ }^{26}$ Our main sample consists of 196,586 domestic manufacturing firms with at least 20 employees located in 80 countries. The histogram in Figure 3 reports the distribution of vertical integration indices for all firms in our main sample. According to our measure, most firms produce relatively few inputs in house: the median vertical integration index is around 0.044 and the mean is $0.063 .^{27}$

\subsection{Tariffs and other trade variables}

Our main strategy to empirically assess the impact of market prices on ownership structure is to use data on applied most-favored-nation (MFN) tariffs, which offer a plausibly exogenous source of price variation to the boundaries of the firm. As argued in the introduction, the degree of vertical integration of a firm is unlikely to have a systematic impact on the determination of trade policies in general, and MFN tariffs in particular. These are negotiated at the multilateral level over long periods of time and are less "political" than unilateral forms of protection such as anti-dumping duties.

We collect applied MFN tariffs at the 4-digit SIC level for all WTO members for which this information is available. We restrict the set of countries to WTO members, which are constrained under Article I of the GATT by the MFN principle of non-discrimination: each country $c$

\footnotetext{
${ }^{25}$ One might be concerned about measuring vertical integration at the firm level, in light of the results by Hortacsu and Syverson (2009), who find little evidence of commodity shipments across commonly-owned plants in US non-multinational firms. However, this concern does not apply to our analysis. This is because $96 \%$ of the firms in our sample have only one plant and $87 \%$ of plants are not connected (see Table A-2). The qualitative results of our analysis are thus unaffected if we measure vertical integration at the plant-level or restrict the analysis to single-plant firms.

${ }^{26}$ The descriptive statics for our vertical integration measure are similar to Acemoglu, Johnson and Mitton (2009). They report a mean of 0.0487 and median of 0.0334 for their vertical integration index. For our main sample, the primary sector vertical integration index has a mean of 0.0627 and a median of 0.0437 (see Table A-2). The ordering of industries by degree of vertical integration in Table A-3 is also similar to that reported by Acemoglu, Johnson and Mitton (2009).

${ }^{27}$ It should be noted that this measure does not consider payments to capital and labor services and is thus always less than unity. Indeed, in the U.S. an industry pays on average around $56 \%$ of gross output to intermediates, the rest being value added. Thus, even a fully vertically integrated firm in a typical sector would have an index of only 0.56 .
} 
Figure 3: Firm-level vertical integration index

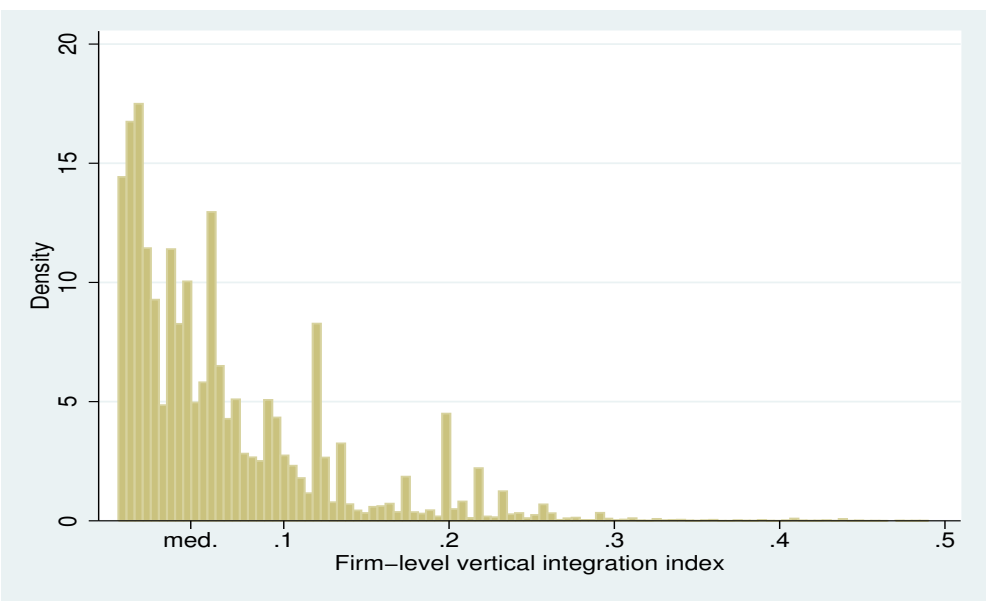

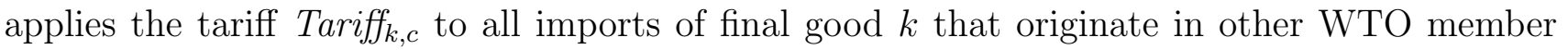
countries; preferential treatment is allowed only for imports originating from RTA members or from developing countries (see discussion below). The source for MFN tariffs is the World Integrated Trade Solution (WITS) database, which combines information from the UNCTAD TRAINS database (default data source) with the WTO integrated database (alternative data source). Tariffs are for 2004 unless unavailable for that year in which case the closest available data point in a five year window around 2004 (2002-2006) is chosen with priority given to earlier years. $^{28}$ The original classification for tariff data is the harmonized system (HS) 6digit classification. Tariffs are converted to the more aggregate SIC 4-digit level using internal conversion tables of WITS. Here, SIC 4-digit level MFN tariffs are computed as simple averages over the HS 6 digit tariffs.

Our analysis focuses on tariffs on final goods in the domestic market. In some regressions, we also control for the tariffs applied to imported inputs, using the variable Input Tariff $f_{k, c}$. This is a weighted average of 4-digit SIC applied MFN tariffs, using normalized IO-coefficients from the US input-output table as weights. To proxy for the level of protection faced by exporters in foreign markets, we use the variable Export Tariff $_{k, c}$. We construct this variable by weighting tariffs in destination markets with bilateral export shares using information from the UN Comtrade database.

The variable $M F N$ share $_{k, c}$ measures the fraction of imports to which MFN tariffs apply, for each country and sector. This excludes imports from countries with which the importer has a preferential trade agreement, which do not face tariff restrictions. The higher is this share, the more sensitive domestic prices should be to MFN tariffs. For example, the U.S. will have low MFN shares in sectors in which it imports a lot from its NAFTA trading partners (Canada and

\footnotetext{
${ }^{28}$ For example, if data are available for 2003 and 2005, but not 2004, the 2003 data are chosen.
} 
Mexico). In these sectors, the MFN tariff that the U.S. imposes on other WTO members will have little impact on domestic prices. In contrast, the effect may be substantial in sectors where most imports originate in countries with which the U.S. has no preferential trade agreement.

To distinguish between firms selling only in the domestic market and exporting firms, we construct two measures. The dummy variable Domestic $_{f}$ is constructed from WorldBase and takes the value of 1 if firm $f$ does not report to be an exporter. The variable Import-competing $g_{k, c}$ is a country-sector specific measure of import-competition constructed using information from Comtrade. This is a dummy indicating whether a firm operates in one of the 25 percent most import-competing sectors, based on the ratio of a country's total imports/exports by sector.

We also collect information on all regional trade agreements in force in 2004 from the WTO Regional Trade Agreements Information System (RTA-IS). ${ }^{29}$ The legal basis for the creation of RTAs can be found in GATT/WTO Article XXIV (for agreements involving developed member countries) and the Enabling Clause (for agreements among only developing countries). Under Article XXIV, member countries can form free trade areas (FTAs) or customs unions (CUs) covering "substantially all trade", that require complete duty elimination and fixed timetables for implementation. The conditions contained in the Enabling Clause being much less stringent, RTAs between developing member countries may effectively involve less trade liberalization. Thus we construct the dummy $R T A_{c, c^{\prime}}$ that equals one when countries $c$ and $c^{\prime}$ belong to a common trade agreement formed under Article XXIV. ${ }^{30}$ To distinguish between different types of RTAs, we construct the dummy variables Customs Union ${ }_{c, c^{\prime}}$ and Free Trade Area C,c $^{\prime}$. We expect the former, which imply a common external tariff and no internal trade barriers, to have a stronger effect on organizational convergence than the latter, which permit member countries to maintain different external tariffs.

\subsection{Other controls}

We collect a number of country- and sector-specific variables to control for alternative factors emphasized in the literature on vertical integration.

In terms of country-specific variables, the empirical and theoretical literatures have studied the role of institutional characteristics and financial development. ${ }^{31}$ We use the variable Legal Quality c to proxy for the quality of a country's institutions. This is the variable "rule of law" from Kaufmann, Kraay, and Mastruzzi (2003), which is a weighted average of a number of variables (perception of incidences of crime, effectiveness and predictability of the judiciary, and

\footnotetext{
${ }^{29}$ Available online (http://rtais.wto.org/UI/PublicMaintainRTAHome.aspx).

${ }^{30}$ This variable does not include a number of preferential trade agreements under the Enabling Clause that do not imply the full elimination of trade barriers.

${ }^{31}$ Poor legal institutions may affect vertical integration decisions through their impact on the severity of holdup problems. A sufficient level of financial development may be necessary for upstream and downstream firms to be able to integrate. As Acemoglu, Johnson and Mitton (2009) note, the effect of each of these variables may be ambiguous when considered separately and there are more robust predictions of their combined effect.
} 
enforceability of contracts) between 1997 and 1998. The variable ranges from 0 to 1 and is

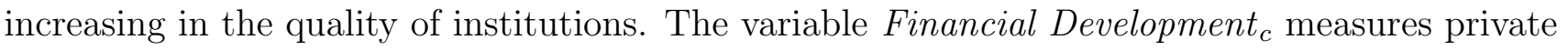
credit by deposit money banks and other financial institutions as a fraction of GDP for 2004 and is taken from Beck, Demigurc-Kunt, and Levine (2006).

We also construct the variable Capital Intensity $_{k}$, using data from the NBER-CES manufacturing industry database (Bartelsmann and Gray, 2000) at the 4-digit-SIC level. In line with the literature, capital intensity is defined as the log of total capital expenditure relative to value added averaged over the period 1993-1997.

To control for domestic industry concentration, we construct Herfindahl ${ }_{k, c}$ indices using information on sales of all plants in a given country and sector. ${ }^{32}$

To proxy for the degree of product differentiation, we use two dummy variables. The variable Homogeneous $1_{k}$ is equal to 1 when a sector is homogeneous according to the well-known classification by Rauch (1999). ${ }^{33}$ The dummy variable Homogeneous2 ${ }_{k, c}$ is constructed using information on sector-country-specific import demand elasticities estimated by Broda, Greenfield and Weinstein (2006). ${ }^{34}$ It takes value 1 whenever the elasticity is above the median for the country. Broda, Greenfield and Weinstein (2006) show that sectors with more homogeneous products are characterized by higher import demand elasticities.

In some specifications, we include the variable $S_{i z e}$, using information on firm-level employment from WorldBase. Since firm size is clearly endogenous to vertical integration, we always use predicted size as an instrument, constructed by regressing firm size on sector-country dummies. Similarly, we construct labor productivity measured as firm sales divided by employment. Again, we instrument this variable using predicted (with sector-country dummies) labor productivity.

In the regressions on organizational convergence, we also use a number of bilateral variables from CEPII: bilateral Distance measured as the simple distance between the most populated cities (in km), dummies for Contiguity C,c $^{\prime}$, for Common Language Co, $^{\prime}$ (official or primary), and Colonial Relationship $p_{c, c^{\prime}}$ (current or past). In some specifications, we also include the variable Difference $G D P_{c, c^{\prime}}$ for the year 2004 constructed from the World Development indicators.

\section{Tariffs and vertical integration}

In this section, we assess the empirical validity of the main prediction of our theoretical model that higher prices for the final good lead to more vertical integration at the firm level. The section is divided in two parts. First, we exploit cross-sectional variation in applied MFN tariffs to verify whether trade policy affects firms' ownership structures in the way predicted by our

\footnotetext{
${ }^{32}$ These include sales by foreign-owned plants that operate in the given country-sector.

${ }^{33}$ Rauch (1999) classifies products according to three different types: homogeneous goods, which are traded in organized exchanges; goods that are are not traded in organized exchanges, but for which a published reference price can be found; and differentiated goods, which fall under neither of the two previous categories.

${ }^{34}$ We thank David Weinstein for making these data available to us.
} 
model. Second, we exploit time-series variation in the degree of protection faced by firms, examining the organizational effects of China's accession to the WTO.

\subsection{Cross-sectional evidence}

To examine the organizational effects of trade policy, we first exploit variation in applied MFN output tariffs across countries and sectors. We estimate the following reduced form regression model:

$$
V_{f, k, c}=\alpha+\beta_{1} \operatorname{Tariff}_{k, c}+\beta_{2} \mathbf{X}_{f, k, c}+\delta_{k}+\delta_{c}+\epsilon_{f, k, c}
$$

where $\mathbf{X}_{f, k, c}$ is the vector of explanatory variables, $\delta_{k}$ and $\delta_{c}$ are sector and country dummies and $\epsilon_{f, k, c}$ is an error term with $E\left(\epsilon_{f, k, c} \mid \mathbf{X}_{f, k, c}, \delta_{k}, \delta_{c}\right)=0$. Thus, the effect of Tariff $f_{k, c}$ on $V_{f, k, c}$ is causal conditional on covariates.

We study the determinants of $V_{f, k, c}$, the vertical integration index of firm $f$, with primary sector $k$, located in country $c$, as defined in (3). Since the distribution of vertical integration indices is rather skewed (see Figure 3), we use log of one plus $V_{f, k, c}$ as our dependent variable. ${ }^{35}$

Our main regressor of interest is the variable $\operatorname{Tariff}_{k, c}$, which is the log of (one plus) the MFN tariff applied to output in sector $k$ by country $c{ }^{36}$ Our model predicts that higher final good tariffs within an industry should lead firms in that industry to be more vertically integrated. We thus expect the coefficient $\beta_{1}$ to be positive. ${ }^{37}$

The vector $\mathbf{X}_{f, k, c}$ includes a series of firm- and sector-country-specific controls, that we will discuss below. We also include sector fixed effects at the 4-digit SIC level $\left(\delta_{k}\right)$, which allows us to capture cross-industry differences in technological or other determinants of vertical integration (e.g., a sector's capital intensity). Finally, we add country fixed effects $\left(\delta_{c}\right)$, which capture cross-country differences in institutional determinants of vertical integration (e.g., a country's level of financial development and the quality of its contracting institutions) and also control for country-specific differences in the way firms are sampled. Given that tariffs vary only at the sector-country level, while the dependent variable varies at the firm level, we cluster standard errors at the sector-country level.

\footnotetext{
${ }^{35}$ We have also used the log of the vertical integration index (removing zero observations), obtaining similar results. There are very few zeros in the dependent variable, so there is no need to perform a Tobit analysis. All results not shown due to space considerations are available upon request.

${ }^{36}$ Tariffs are expressed in ad-valorem terms. In the main specifications, we use log of (one plus MFN tariff) in order to be able to include zero tariffs. Although the distribution of tariffs is extremely skewed, $\log$ tariffs are approximately normally distributed. Using, in alternative specifications, the log of the tariff variable yields similar results.

${ }^{37}$ We have also performed a series of estimations including a quadratic term for Tariff $k, c$, finding no evidence of a non-monotonic relationship between tariffs and vertical integration.
} 


\subsubsection{Main results}

Table 1 reports the results of estimations in which we test the main predictions of our theoretical framework.

Column (1) presents the results of the basic specification, which includes only the variable Tariff and country and sector fixed effects. The estimated coefficient for the tariff is positive and strongly significant. Consistently with the first prediction of our theoretical model, higher tariffs lead firms to be more vertically integrated. The point estimate for $\beta_{1}$ implies that a 100 percent tariff increase leads to a 2.03 percent increase in the vertical integration index. In terms of economic magnitudes, this implies that an increase in manufacturing tariffs from 1 percent to their mean level of 4.85 percent (a 385 percent increase) increases vertical integration by $0.0203^{*} 385=7.82$ percent. $^{38}$

The estimate for $\beta_{1}$ can be interpreted as the impact of prices on vertical integration if and only if prices and tariffs vary one to one. This would be true for a specific (per-unit) tariff imposed by a small country in a competitive environment. In the case of ad-valorem tariffs, the relation would be weaker. This would also be true if the country is large, i.e., can affect world prices. In this case, imposing a tariff will have an impact on the world price and the elasticity of domestic prices with respect to tariffs will be less than one. ${ }^{39}$ Ideally, one would use industry-level price indices and instrument them with tariffs. Unfortunately, reliable price data is unavailable. ${ }^{40}$ These arguments imply that the estimate for $\beta_{1}$ should be interpreted as a lower bound on the impact of prices on vertical integration.

In columns (2) and (3) we verify whether the effect of domestic tariffs on organization is larger for firms that operate only in the domestic market (for which only this price should affect the degree of vertical integration). To do so, we interact the variable Tariff $f_{k, c}$ with two dummy variables: Domestic $_{f}$, which is constructed using information on from WorldBase and takes the value of 1 if firm $f$ does not report to be an exporter; and Import-competing ${ }_{k, c}$, which is constructed using information from Comtrade and indicates whether a firm operates in one of the 25 percent most import-competing sectors, based on the ratio of a country's total imports/exports by sector. We expect the coefficients on the interaction terms to be positive.

In column (2), the coefficient for tariffs (which measures the impact of tariffs on vertical

\footnotetext{
${ }^{38}$ The coefficient for Tariff in the log-log specification, where we have only 149,574 observations since we lose observations with zero tariffs, is 0.03 and significant at the one-percent level. This implies that an increase in manufacturing tariffs by 385 percent increases vertical integration by $0.03 * 385=11.55$ percent.

${ }^{39}$ Denote the domestic price of good $k$ in country $c$ as $p_{k, c}=\left(1+t_{k, c}\right) P_{k}$, where $P_{k}$ is the world price of good $k$. Then $\frac{\partial p_{k, c}}{\partial t_{k, c}} \frac{t_{k, c}}{p_{k, c}}=\frac{t_{k, c}}{1+t_{k, c}}+\frac{\partial P_{k}}{\partial t_{k, c}} \frac{t_{k, c}}{P_{k}}$, where the first part on the right is the direct impact of an ad-valorem tariff on domestic prices $(<1)$ and the second term is the terms of trade effect $(<0)$. Notice also that, to the extent that countries are able to manipulate tariffs to improve their terms of trade, high tariffs are likely to be observed precisely in sectors in which they increase domestic prices only by a small amount. Broda, Limao and Weinstein (2008) provide evidence that non-WTO countries exploit their market power in trade by setting higher tariffs on goods that are supplied inelastically.

${ }^{40}$ Unit values cannot be used for our purposes: we require data on domestic prices, while unit values (CIF or FOB) are measures of import prices at the border, before tariffs are applied.
} 
integration for exporters) is positive but insignificantly different from zero. On the other hand, the coefficient on the interaction term is positive, strongly significant and similar in magnitude to the baseline specification. Thus, import tariffs have a significant affect on vertical integration only for firms that sell only in the domestic market. In column (3), we use the alternative measure to identify firms that do not export to foreign markets. Again, the coefficient on the interaction term is positive and significant at the five-percent level, indicating that import tariffs have a bigger impact on vertical integration decisions for firms that operate in import-competing sectors.

In column (4) we test if tariffs have a larger impact on vertical integration when the share of imports to which they apply is larger (and thus domestic prices should be more affected). To do this, we include the variable $M F N$ share $_{k, c}$, capturing the fraction of imports to which MFN tariffs apply in a given country and sector, as well as the interaction between this variable and the tariff. The coefficient in the first row now measures the impact of MFN tariffs when no imports are subject to them (i.e., in a sector in which a country imports only from regional trading partners). Not surprisingly, this coefficient is not significant, since in this case MFN tariffs should have no impact on the price faced by domestic firms. The interaction term is instead positive and significant at the one-percent level, indicating that the effect of MFN tariffs on vertical integration is positive and increasing in their importance for import volumes.

In columns (5)-(8) we repeat the same specifications, adding institutional interaction terms that have been emphasized in previous studies on vertical integration. In particular, Acemoglu, Johnson and Mitton (2009) find evidence that contracting costs and financial development have a stronger impact on vertical integration in more capital-intensive sectors. We thus introduce two interaction terms: one between Capital Intensity ${ }_{k}$ and Financial Development ${ }_{c}$ and the other one between Capital Intensity In Legal Quality $_{c}$. The coefficient on the first interaction term is positive and significant, indicating that more capital intensive sectors are more integrated in countries with more developed financial markets. The second interaction term has the expected negative sign but it is not significant. In all specifications, our results on the effect of tariffs on vertical integration are unaffected.

\subsubsection{Prices versus competition}

Our theoretical analysis focuses on a perfectly competitive setting, in which firms are price takers. According to our model, tariff changes should affect organizational choices through their impact on product prices: higher tariffs should lead firms to vertically integrate, by raising prices and thus increasing the value of coordination. In reality, tariff changes may also affect vertical integration decisions through their impact on the degree of competition faced by firms. In particular, Aghion, Griffith and Howitt (2006) suggest a U-shaped relationship between competition and vertical integration: a small increase in competition reduces a producer's incentive to 
integrate by improving the outside options of non-integrated suppliers and hence raising their incentive to make relationship-specific investments; too much competition raises the producer's incentive to integrate, by allowing non-integrated suppliers to capture most of the surplus.

In Table 2, to isolate the organizational effects of product prices, we restrict our analysis to highly competitive sectors, in which tariffs changes should have little or no effect on the degree of competition. In all specifications, we impose two restrictions to define competitive industries: i) there are at least 20 domestic firms operating in that country and sector; ii) goods are homogeneous. Further restrictions are imposed in some specifications, as discussed below. To distinguish between differentiated and homogeneous sectors, we adopt two alternative methodologies: in Panel A, we use the dummy variable Homogeneous $1_{k}$, which identifies industries in which goods are traded in organized exchanges, classified as homogeneous according to Rauch (1999); in Panel B, we use instead the variable Homogeneous $\mathcal{L}_{k, c}$, which identifies sectors with high import demand elasticities according to Broda, Greenfield and Weinstein (2006). Notice that the sample is much larger in the bottom panel, since the variable Homogeneous2 $2_{k, c}$ varies at the country-sector level.

In the baseline specifications of columns (1)-(2), competitive sectors are identified based only on the two criteria discussed above. Additional restrictions are imposed in the rest of the table. Columns (3)-(4) include only sectors with low levels of protection (Tariff $f_{, c}<10 \%$ ), in which domestic firms face a high level of foreign competition. In columns (5)-(6) the sample is restricted to sectors in which some foreign-owned firms operate in the domestic market, further increasing the competitive pressure on domestic firms. In columns (7)-(8), we exclude from our analysis concentrated sectors, i.e., industries for which the Herfindahl $l_{k, c}$ index is above 0.1.

In all specifications, the coefficient for $\operatorname{Tariff}_{k, c}$ is positive and significant at least at the fivepercent level. The results of Table 2 allow us to identify the price-level effects of tariff changes on firm boundaries, abstracting from possible competition effects. In line with our theoretical model, these results suggest that higher import tariffs lead domestic firms to be more vertically integrated, by increasing the price at which they sell their final products. Comparing Tables 1 and 2 we can see that, when we restrict the analysis to highly competitive sectors, the estimates for the import tariffs are up to three times larger in magnitude and more significant. This suggests that, when firms have little or no market power, tariffs changes have a bigger impact on domestic prices (i.e., larger "tariff-pass through") and thus on organizational choices.

\subsubsection{Omitted variables}

Our analysis shows that firms are more vertically integrated when import tariffs on their final product are higher. In this section, we deal with endogeneity concerns, establishing a causal relationship between tariffs and organization decisions. As argued above, reverse causality is unlikely to be a problem in our analysis, since there is no reason to believe that vertically 
integrated firms should be particularly interested or able to obtain high levels of protection. However, MFN tariffs on final products could be correlated with omitted variables that also affect firms' ownership structures.

In what follows, we show that our results are robust to controlling for two sets of potential omitted variables. First, we include measures of input tariffs and export tariffs, which are correlated with output tariffs ${ }^{41}$ and may also affect vertical integration decisions. Second, we control for firm size, labor productivity and industry concentration, which can affect the degree of protection through their impact on lobbying pressure (e.g., Mitra, 1999; Bombardini, 2008) and may also be correlated with firms' ownership structures.

The results of these regressions are presented in Table 3. For comparison, in the first two columns, we report the results of the baseline specifications. In column (3)-(8), we add additional controls, first one by one and then simultaneously: Input Tariff $k, c$, Export Tariff ${ }_{k, c}$, Herfindahl $_{k, c}$,

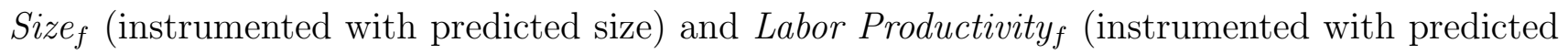
labor productivity). Notice that, in all specifications, the coefficient on Tariff is positive, highly significant, and very stable. These results indicate that omitted variables are not a concern and that higher output tariffs lead to more vertical integration. Of the additional controls, input tariffs, firm size, and labor productivity have a (positive) significant effect on organization. ${ }^{42}$

\subsubsection{Additional robustness checks}

In line with the predictions of our theoretical model, our empirical analysis shows that higher output tariffs lead domestic firms to be more vertically integrated. This effect is stronger for firms serving only the domestic market — for which organizational choices should depend solely on domestic prices - and operating in sectors in which a smaller share of imports originate from regional trading partners — for which MFN tariffs should have a larger impact on domestic prices.

The results presented in Tables 1-3 already show that the organizational effects of tariffs are robust to the inclusion of many different controls that account for alternative drivers of vertical integration decisions. In a series of additional robustness checks, we have verified that higher tariff on final goods continue to have a positive and significant effect on firm-level vertical integration when using different econometric methodologies or focusing on alternative samples.

In Table A-4 in the Appendix, we reproduce all the specifications of Table 3, using a Poisson quasi-maximum likelihood (PQML) estimator to assess the effect of tariffs on vertical integration. The rationale for this exercise is that Santos Silva and Tenreyro (2006) have shown that for loglinear models the OLS estimator gives inconsistent estimates in the presence of heteroscedasticity

\footnotetext{
${ }^{41}$ The simple correlation of output tariffs with input tariffs is 0.78 and the one with export tariffs is 0.31 .

${ }^{42}$ The coefficients on firm size and labor productivity remain positive and significant in all robustness checks (e.g., Table A-4). This is in line with our theoretical model, in which firms with higher levels of $R$ are more integrated for a given price level.
} 
and have suggested the PQML estimator as an alternative with good statistical properties. Vertical integration is now estimated in levels, which allows to include observations for which the dependent variable is zero, while the explanatory variables are in logs and can thus be interpreted as elasticities. Standard errors are again clustered at the sector-country level. Our main result on the impact of output tariffs is unaffected: in all specifications, the coefficient for the output tariff is always positive and significant. Input and export tariffs have instead no significant effect on firm-level vertical integration.

The organizational effects of output tariffs were also unaffected in a series of additional estimations discussed below. The results of these specifications are omitted from the paper due to space considerations, but are available upon request.

We have used an alternative measure of vertical integration, constructed based on all the firm's activities rather than its primary activity: $\bar{V}_{f, k, c}=\frac{1}{N_{f}} \sum^{j} V_{f, k, c}^{j}$, where $N_{f}$ is the number of industries in which firm $f$ is active. The coefficients for MFN tariffs remained strongly significant but, not surprisingly, they dropped slightly in magnitude.

In our analysis, we cluster standard errors at the sector-country level. Alternatively, we have tried clustering at the sector or at the country level. In both cases, the coefficient for Tariffk,c remained strongly statistically significant.

We have also carried out the analysis on three different samples of firms. First, we have restricted the sample to OECD countries. Our methodology for constructing vertical integration indices better applies to these countries: since they are more similar to the United States in terms of technology, it is less problematic to use U.S. input-output matrix to measure technological linkages between sectors. Moreover, in OECD countries there is little or no concern that tariffs may be endogenous to firm decisions: the MFN tariffs applied by these countries coincide with the bindings set in the Uruguay Round of multilateral trade negotiations (1986-1994), so there is little or no room for governments to adjust them under the pressure of firms. ${ }^{43}$ Second, we have restricted the sample to countries for which we observe at least 1000 plants of sufficient size in order to eliminate any bias that may arise from differences in sampling across countries. Third, we have included multinational firms to the main sample. As noted above, since multinationals have plants in different countries, it is hard to identify with precision the tariffs that affect their organization decisions; we have thus split them into separate firms by country and used the primary activity of the respective domestic ultimate to identify the relevant tariff. For each of these three samples, we have reproduced all the specifications of Table 3, adding a dummy variable for multinational status for the sample including multinationals. As expected, the

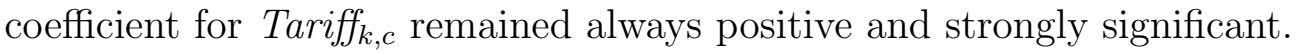

\footnotetext{
${ }^{43}$ In more developed countries like the OECD, the difference between the applied MFN tariff and the bound rate (the "binding overhang") is very small, particularly for non-agricultural products. In contrast, developing countries often apply MFN tariffs that are below the bound rates negotiated in multilateral negotiations.
} 


\subsection{Time-series evidence: China's accession to the WTO}

As noted in the introduction, China's accession to the WTO in 2001 is arguably the only major trade liberalization episode that has occurred in the last decade, for which we can use D\&B data to construct vertical integration measures. To be accepted as a member of the WTO, China agreed to undertake a series of important commitments to better integrate in the world economy and offer a more predictable environment for trade and foreign investment in accordance with WTO rules. ${ }^{44}$ In particular, China had to substantially expand market access to goods from foreign countries, reducing its import tariffs from an average of 13.3 percent in 2001 to 6.8 percent by the end of the implementation period. ${ }^{45}$

Our identification strategy is based on the comparison of two periods, a pre-accession one and a post-accession one, to verify whether firm-level vertical integration was reduced by more in those sectors that experienced larger tariff cuts. We thus construct vertical integration measures for all Chinese manufacturing firms that are in the WorldBase dataset for the years 1999 (pre accession) and 2007 (post accession), following the same procedure described in Section 3.3. We use 2007 instead of 2004 as the post-accession period because we expect firms' ownership structure to react slowly to price changes induced by tariff reductions.

Figure 4 provides the histograms of the MFN tariffs applied by China in 1999 and 2007. The sample is based on those manufacturing sectors for which we observe firms (with at least 20 employees, excluding multinationals) in both years, consisting of almost 29,000 firms that we observe in at least one year. For the sectors in this sample, applied tariffs fell from an average 20 to an average of 9.9 percent between 1999 and 2007, with a lot variation across sectors. ${ }^{46}$ At the same time, the average level of vertical integration for the sample of firms declined from 0.111 to $0.084^{47}$ Figure 5 visualizes the leftward shift in the distribution of VI indices between 1999 and 2007.

In what follows, we examine whether Chinese firms have adjusted their vertical integration structure following WTO accession in response to the tariff reductions. To this purpose, we run two sets of regressions. First, we use a very similar specification as in our main test (4), using

\footnotetext{
${ }^{44}$ A detailed list of China's commitments can be found in its Protocol of Accession. China's accession implied few trade policy changes for other WTO members, since most of them had already been granting it MFN status.

${ }^{45}$ The implementation period lasted until 2010, though most tariff reductions had to be completed by 2005 .

${ }^{46}$ The maximum reduction in tariffs was 415 percent (SIC 3578, Calculating and Accounting Machines), the median reduction was 51 percent. Only in a few sectors, tariffs did not change or actually increased (e.g., SIC 2084 Wines, Brandy and Brandy Spirits).

${ }^{47}$ One may be concerned that tariff levels and reductions may be endogenous to industry characteristics, for example because industries with larger firms, more concentrated industries, or industries with more prevalence of public ownership would lobby for higher initial tariff levels and smaller subsequent tariff reductions. If on the other hand, these sectors are systematically different in terms of vertical integration, one may spuriously obtain negative correlations between vertical integration and tariffs. In our sample, however, this is not the case: the level of tariffs in 1999 is neither significantly correlated with sector-level average firm size, nor with industry concentration or public ownership in the same year. Moreover, changes in tariffs between 1999 and 2007 are also not significantly correlated with the level of the previous variables in 1999.
} 
Figure 4: Chinese import tariffs, 1999 and 2007

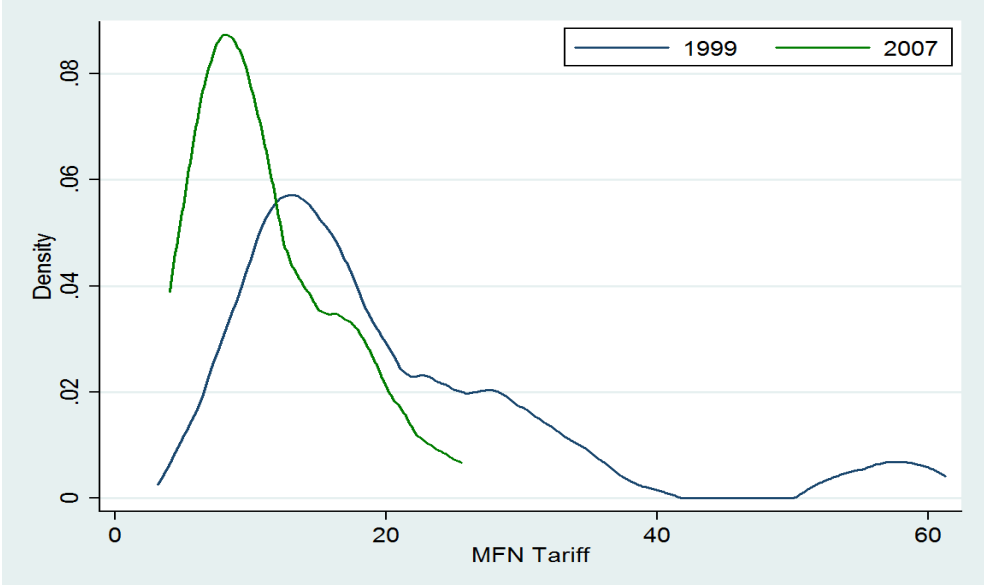

Figure 5: Chinese vertical integration indices, 1999 and 2007

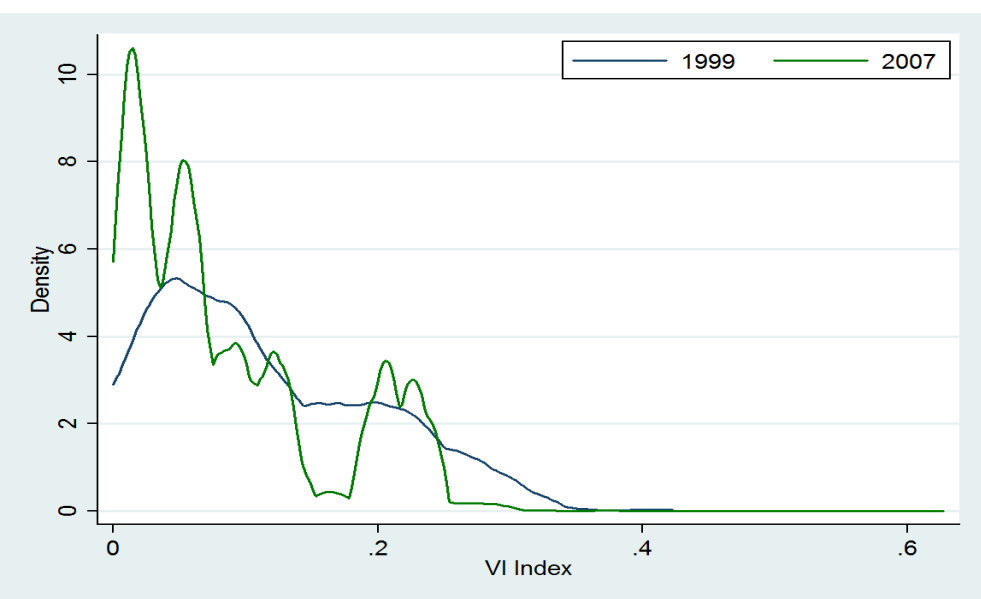

only those sectors for which we observe some firms in both 1999 and in 2007:

$$
V_{f, k, t}=\alpha+\beta_{1} \operatorname{Tariff}_{k, t}+\beta_{2} \mathbf{X}_{f, k, t}+\delta_{k}+\delta_{t}+\epsilon_{f, k, t}
$$

Here, $\mathbf{X}_{f, k, t}$ is again a vector of controls, which includes $P u b l i c_{f, t}$, a dummy for public ownership from Worldbase, and Herfindahl $l_{k, t}$. We control for Public f $_{f, t}$ since public ownership is very common in China and may be correlated with vertical integration. Again, we expect the coefficient of Tariff $k, t$ to be positive. Notice that, by controlling for sector fixed effects, we exploit the time variation of tariffs within sectors. Specifically, the tariff coefficient is identified by the deviation of firm-level vertical integration from its sector mean that is due to the time variation in tariffs relative to their sector mean. Given that we only consider sectors for which we can observe firms in both periods, sector averages of vertical integration and tariffs are well identified. General 
trends in vertical integration, which may be due to other reforms that occurred in China over the sample period, are picked up by time dummies. ${ }^{48}$

In a second set of regressions, we focus on within-firm variation in VI indices. Unfortunately, the overlap between the firms sampled in 1999 and 2007 is small. Once we exclude multinationals and plants with less than 20 employees, as we have done in our earlier analysis, there are 145 firms that we can observe in both years. For this set of firms, we take time differences of equation (5) and estimate

$$
\Delta V_{f, k}=\alpha+\beta_{1} \Delta \operatorname{Tariff}_{k}+\beta_{2} \Delta \mathbf{X}_{f, k}+\Delta \epsilon_{f, k}
$$

Again, we expect the coefficient of $\Delta$ Tariff $_{k}$ to be positive. In these regressions, we control not only for changes in firm size, industry concentration and public ownership status, but alternatively also for changes in the degree of state ownership by sector, by including the variable Privatization. This measures the fraction of government-owned firms that were privatized in a given sector (at the 2-digit industry level) between 1999 and 2004 and is taken from Bai, Lu and Tao (2009).

Table 4 presents the results for both sets of regressions. Columns (1)-(4) reports the results for the regressions with sector dummies. In all specifications, we find a positive and significant (at the one percent level) coefficient on the tariff variable, implying larger reductions in vertical integration in sectors that have experienced larger tariff reductions. The coefficient magnitude is around 0.03, which is slightly larger than our cross-section estimates. The coefficient of the public-ownership dummy is positive and highly significant, indicating that publicly owned firms are more vertically integrated. Finally, the level of industry concentration has no significant effect on vertical integration.

Turning to the specification in differences, in columns (5)-(10) we obtain similar results. The coefficient of tariff changes is always positive, significant and similar in magnitude to the specification with sector dummies. In column (6) we add changes in industry concentration as control, which leaves the tariff coefficient unaffected. Column (7) adds change in public ownership status as control, which is insignificant and does not change the tariff coefficient. In column (8) we alternatively use Privatization as a control, which is again insignificant and also leaves the coefficient of tariffs unchanged. Finally, in columns (9) and (10), we simultaneously control for changes in public ownership structure and changes in industry concentration by adding the Herfindahl index. While changes in tariffs remain positive and significant, changes in industry concentration and changes in public ownership have no significant effects.

\footnotetext{
${ }^{48}$ In these regressions, unobserved firm-specific effects are assumed to be common for all firms in a given sector.
} 


\section{Trade policy and organizational convergence}

The purpose of this section is to assess the validity of the predictions of our model on how trade policy affects organizational convergence between countries, through its impact on price convergence.

To measure organizational convergence, we construct sector-country-specific measures of vertical integration by regressing firm-level vertical integration on industry-sector dummies and firm size. The estimate for the sector-country dummy gives us a measure of the average level of vertical integration of industry $k$ in country $c$, denoted by $\hat{V}_{k, c}$.

We first examine whether cross-country differences in sectoral organizational structure are affected by differences in tariffs. Our model predicts that, for a given country-pair $c c^{\prime}$, organizational differences should be smaller for sectors characterized by similar levels of protection. To verify this, we estimate the following model:

$$
\left|\hat{V}_{k, c}-\hat{V}_{k, c^{\prime}}\right|=\alpha+\beta_{1}\left|\operatorname{Tariff}_{k, c}-\operatorname{Tariff}_{k, c^{\prime}}\right|+\beta_{2}\left|\mathbf{X}_{k, c}-\mathbf{X}_{k, c^{\prime}}\right|+\delta_{k}+\delta_{c, c^{\prime}}+\epsilon_{k, c, c^{\prime}} .
$$

The dependent variable is the absolute difference between countries $c$ and $c^{\prime}$ in the estimated vertical integration indices for sector $k$. All differences are expressed in logs. The main regressor of interest is the (log of the) absolute difference between these countries' MFN tariffs in sector $k$. The term $\left|\mathbf{X}_{k, c}-\mathbf{X}_{k, c^{\prime}}\right|$ captures differences in other sector-country characteristics that may affect the degree of organizational convergence. Note that, because we are including dyad fixed effects $\left(\delta_{c, c^{\prime}}\right), \beta_{1}$ is identified by the cross-sectoral variation in the tariff difference for a given country pair. To allow for correlation of the errors between sectors for a given country pair, we cluster standard errors by dyad.

The results of these regressions are reported in Panel A of Table 5. In column (1), the only explanatory variable is the log-difference in MFN tariffs. In line with our predictions, we find that, for a given country-pair differences in sectoral vertical integration indices are significantly (at the one percent level) larger in sectors in which differences in MFN tariffs are larger. A 100 percent increase in the difference in MFN tariffs leads to a roughly 0.9 percent increase in the difference in vertical integration indices. The second column adds interactions between Capital Intensity and differences in Financial Development and Legal Quality. The coefficient on the difference in MFN tariffs remains relatively unchanged in magnitude and is significant at the 5 percent level.

We next examine the relation between the degree of sectoral organizational convergence and common membership in a regional trade agreement. In contrast to the regressions on tariff differences, a causal interpretation of these regression results is more difficult, since it is possible that countries that are generally more similar are more likely to form RTAs.

To assess the validity of our final empirical prediction, we explore how RTAs affect the extent 
to which two countries have similar vertical integration structures at the industry level.

$$
\left|\hat{V}_{k, c}-\hat{V}_{k, c^{\prime}}\right|=\alpha+\beta_{1} R T A_{c, c^{\prime}}+\beta_{2} \mathbf{X}_{c, c^{\prime}}+\delta_{k}+\delta_{c}+\delta_{c^{\prime}}+\epsilon_{k, c, c^{\prime}}
$$

The dependent variable is as in model (7), expressed as before in logs. The main regressor of interest is now $R T A_{c, c^{\prime}}$, a dummy that equals one if countries $c$ and $c^{\prime}$ are members of the same RTA. The vector $\mathbf{X}_{c, c^{\prime}}$ captures a series of bilateral controls, such as dummies for contiguity, common language, and colonial relationship, as well as variables that capture the distance between countries, and differences in GDP (differences expressed in logs of absolute values). Finally, we include sector fixed effects $\left(\delta_{k}\right)$ and country fixed effects $\left(\delta_{c}\right.$ and $\left.\delta_{c^{\prime}}\right)$. Standard errors are clustered by country-pair.

The results of these regressions are reported in Panel B of Table 5. In column (1), in which we include only a dummy for regional trade agreements, the coefficient of RTA is negative and significant at the one-percent level. This implies that the difference in vertical integration indices for a country pair in an RTA is about 9.2 percent smaller than for a country pair without an RTA. The results for an alternative specification, which separates customs unions (CUs) from free trade areas (FTAs), are presented in column (2). As expected, the quantitative impact on organizational convergence is greater for CUs than for FTAs. Country pairs that belong to the same CU have a approximately $18.5 \%$ smaller difference in organizational structure than country pairs without a RTA, while membership to FTAs has no significant impact on differences in organizational structure. In column (3), we keep the coefficients for CUs and FTAs separate and add a series of bilateral control variables that may have an impact on similarity of organizational structure. The coefficient for CUs is reduced somewhat in size, but remains significant at the 10 percent level. Contiguity and common language have a significant negative effect on the difference in vertical integration indices, while differences in GDP have a significant positive effect. Colonial relationship and distance do not affect the degree of organizational convergence.

As done for the results presented in Section 4, we have verified that our findings on trade policy and organizational convergence are robust to using different samples of firms (e.g., restricting the sample of countries included in the analysis, including multinationals). In all specifications, are results continue to hold: tariff differences have a significant positive effect on differences in vertical integration; and membership in RTAs, and CUs in particular, continues to reduce differences in vertical integration among member countries.

\section{Conclusions}

Traditional organizational economics has studied ownership decisions without much regard for markets. Given technology and contractibility, there is a uniquely optimal organizational design, the one that delivers the goods at least cost. Demand plays no role. 
This paper provides evidence for the more recent view that markets do matter and that demand is an essential determinant of firm boundaries. Demand affects product prices, prices affect profitability, and profitability affects the tradeoffs organization designers face when determining ownership structures. This causal link is captured by a model in which vertical integration generates more output than non-integration because of its comparative advantage in coordinating operating decisions. But it imposes higher private costs on enterprise managers, forcing them to accommodate to common ways of doing things. At low prices, the productivity gains from integrating have little value, and managers choose non-integration. At high prices, the relative value of coordination increases, favoring integration.

To assess the validity of the model's predictions, we examine the organizational effects of trade policy, which provides a source of price variation that is exogenous to firms' ownership decisions. We use a new dataset that enables us to construct firm-level vertical integration indices for a large set of countries and industries. To study the link between product prices and firm boundaries, we exploit cross-country and cross-sectoral differences in applied MFN tariffs, as well as time variation in the degree of protection faced by firms. In line with the model's predictions, we find that market conditions - in particular the level of product prices — do affect vertical integration: higher tariffs on final goods lead firms to be more vertically integrated, and this effect is stronger for non-exporting firms, which are more sensitive to domestic prices, and for sectors in which domestic prices are expected to be more sensitive to import tariffs.

Our empirical results thus lend support to a simple model of the determination of firm boundaries. As such, they have implications beyond the positive theory of the firm. If integration generates more output than non-integration, as it does in our model, then organizational choices affect consumer welfare and aggregate economic performance (Legros and Newman, 2012; Conconi, Legros and Newman, 2012). This calls for a reassessment of the effects not only of tariffs, but of any price-distorting policy, in light of its potential impact on the organization and productivity of firms.

\section{References}

Acemoglu, D., P. Aghion, R. Griffith, and F. Zilibotti (2010). "Vertical Integration and Technology: Theory and Evidence," Journal of European Economic Association, 8, 1-45.

Acemoglu, D., S. Johnson, and T. Mitton (2009). "Determinants of Vertical Integration: Financial Development and Contracting Costs," Journal of Finance 63, 1251-1290.

Aghion, P., R. Griffith, and P. Howitt (2006). "Vertical Integration and Competition," American Economic Review Papers and Proceedings 96, 97-102.

Alfaro, L., and A. Charlton (2009). "Intra-Industry Foreign Direct Investment," American Economic Review 99, 2096-2119. 
Antras, P. (2003). "Firms, Contracts, and Trade Structure," Quarterly Journal of Economics $118,1375-1418$.

Bai, C., J. Lu, and Z. Tao (2009). "How Does Privatization Work in China," Journal of Comparative Economics 37, 453-470.

Baker, G., and T. Hubbard (2003). "Make Versus Buy in Trucking: Asset Ownership, Job Design and Information," American Economic Review 93, 551-572.

Baker, G., and T. Hubbard (2004). "Contractibility and Asset Ownership: On-Board Computers and Governance in US Trucking," Quarterly Journal of Economics 119, 1443-1479.

Bartelsman, E. J., and W. Gray (1996). "The NBER Manufacturing Productivity Database," NBER Technical Working Paper 205.

Beck T., A. Demigurc-Kunt, and R. Levine (2006). A New Database on Financial Development and Structure (1960-2006).

Black, S. E., and P. E. Strahan (2002). "Entrepreneurship and Bank Credit Availability," Journal of Finance 57, 2807-2833.

Bloom, N., and J. Van Reenen (2007). "Measuring and Explaining Management Practices Across Firms and Countries," Quarterly Journal of Economics 122, 1351-1408.

Bloom, N., R. Sadun, and J. Van Reenen (2010). "Does Product Market Competition Lead Firms to Decentralize?," American Economic Review 100, 434-438.

Bloom, N., R. Sadun, and J. Van Reenen (2012). "The Organization of Firms Across Countries," forthcoming, Quarterly Journal of Economics.

Bombardini, M. (2008). "Firm Heterogeneity and Lobby Participation," Journal of International Economics 75, 329-348.

Bradford, S. (2003). "Paying the Price: Final Goods Protection in OECD Countries," Review of Economics and Statistics 85,24-37.

Broda, C., J. Greenfield, and D. Weinstein (2006). "From Groundnuts to Globalization: A Structural Estimate of Trade and Growth," NBER Working Paper No. 12512.

Broda, C., N. Limao, and D. Weinstein (2008). "Optimal Tariffs and Market Power: The Evidence," American Economic Review 98, 2032-2065.

Caves, R. E. (1975). "Diversification, Foreign Investment and Scale in North American Manufacturing Industries," Canadian Public Policy 2, 274-276.

Coase, R. H. (1937). "The Nature of the Firm," Economica 4, 386-405.

Conconi, P., Legros, P., and A. F. Newman (2012). "Trade Liberalization and Organizational Change," Journal of International Economics 86, 197-208. 
Fan, J. P. H., and L. H. Lang (2000). "The Measurement of Relatedness: An Application to Corporate Diversification," Journal of Business 73, 629-660.

Finger, J. M., H. K. Hall, and D. R. Nelson (1982). "The Political Economy of Administered Protection," American Economic Review 72, 452-466.

Grossman S. J., and O. D. Hart (1986). "The Costs and Benefits of Ownership: A Theory of Vertical and Lateral Integration," Journal of Political Economy 94, 691-719.

Grossman, G. M., and E. Helpman (1994). "Protection for Sale," American Economic Review 84, 833-850.

Grossman, G. M., and E. Helpman (2002). "Integration Versus Outsourcing In Industry Equilibrium," Quarterly Journal of Economics 117, 85-120.

Guadalupe, M., and J. Wulf (2012). "The Flattening Firm and Product Market Competition: The Effect of Trade Liberalization," American Economic Journal: Applied Economics 4, 105-127.

Harrison, A. E., I. Love, and M. S. McMillian (2004). "Global Capital Flows and Financing Constraints," Journal of Development Economics 75, 269-301.

Hart, O. D., and B. R. Holmström, (2010). "A Theory of Firm Scope," Quarterly Journal of Economics, 125, 483-513.

Hart, O. D., and J. H. Moore (1990). "Property Rights and the Nature of the Firm," Journal of Political Economy 98, 1119-1158.

Holmström, B. and P. Milgrom (1991). "Multitask Principal-Agent Analyses: Incentive Contracts, Asset Ownership, and Job Design," Journal of Law, Economics and Organization $7,24-52$.

Hortaçsu, A., and C. Syverson (2007). "Cementing Relationships: Vertical Integration, Foreclosure, Productivity and Prices," Journal of Political Economy 115, 250-301.

Hortaçsu, A., and C. Syverson (2009). "Why do Firms Own Production Chains? "mimeo.

Hummels, D., J. Ishii, and K. Yi (2001). "The Nature and Growth of Vertical Specialization in World Trade," Journal of International Economics 54, 75-96.

Joskow, P. (1987). "Contract Duration and Relationship-Specific Investments: Empirical Evidence from Coal Markets," American Economic Review 77, 168-185.

Kaufmann, D., A. Kraay, and M. Mastruzzi (2004). "Governance Matters III: Governance Indicators for 1996, 1998, 2000, and 2002," World Bank Economic Review 18, 253-287.

Klapper, L., L. Laeven, and R. Rajan (2006). "Entry Regulation as a Barrier to Entrepreneurship," Journal of Financial Economics 82, 591-629. 
Legros, P., and A. F. Newman (2008). "Competing for Ownership," Journal of the European Economic Association 6, 1279-1308.

Legros, P., and A. F. Newman (2012). "A Price Theory of Vertical and Lateral Integration, forthcoming, Quarterly Journal of Economics.

McLaren, J. (2000). "Globalization and Vertical Structure," American Economic Review 90, 1239-1254.

Mitra, D. (1999). "Endogenous Lobby Formation and Endogenous Protection: A Long-Run Model of Trade Policy Determination," American Economic Review 89, 1116-1134.

Nunn, N. (2007). "Relationship-Specificity, Incomplete Contracts, and the Pattern of Trade," Quarterly Journal of Economics 122, 569-600.

Rauch, J. (1999). "Networks Versus Markets in International Trade," Journal of International Economics 48, 7-35.

Rey, P., and J. Tirole (2007). "A Primer on Foreclosure," in M. Armstrong, and R. Porter (eds.) Handbook of Industrial Organization III, North-Holland.

Salinger, M. A. (1988). "Vertical Mergers and Vertical Foreclosure," Quarterly Journal of Economics 103, 345-356.

Santos-Silva J. M. C and Silvana Tenreyro (2006). "The Log of Gravity," Review of Economics and Statistics 88, 641-658.

Stuckey, J. A. (1983). Vertical Integration and Joint Ventures in the Aluminium Industry. Harvard University Press, Cambridge, MA.

Woodruff, C. (2002). "Non-contractible Investments and Vertical Integration in the Mexican Footwear Industry, International," Journal of Industrial Organization 20, 1197-1224. 


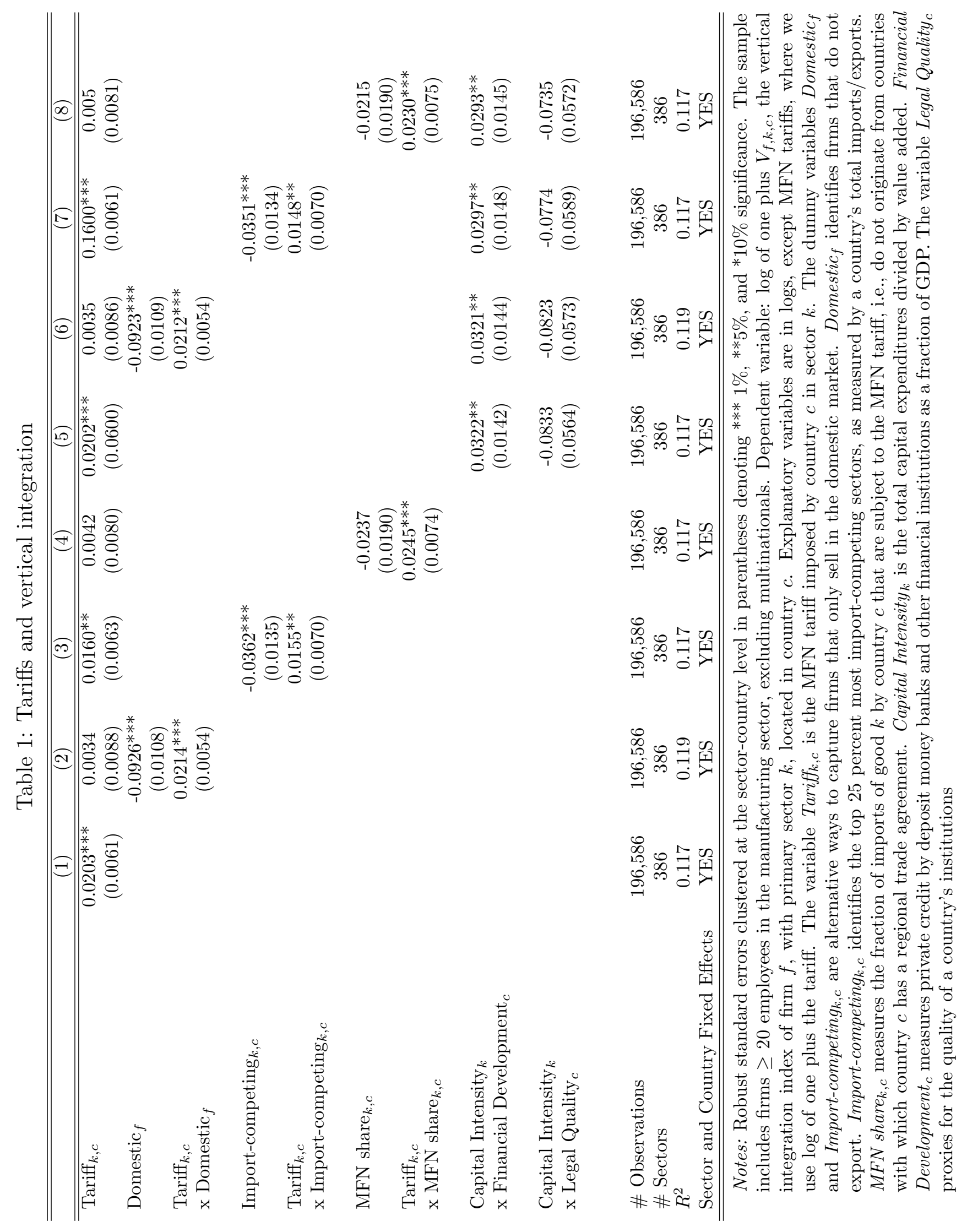




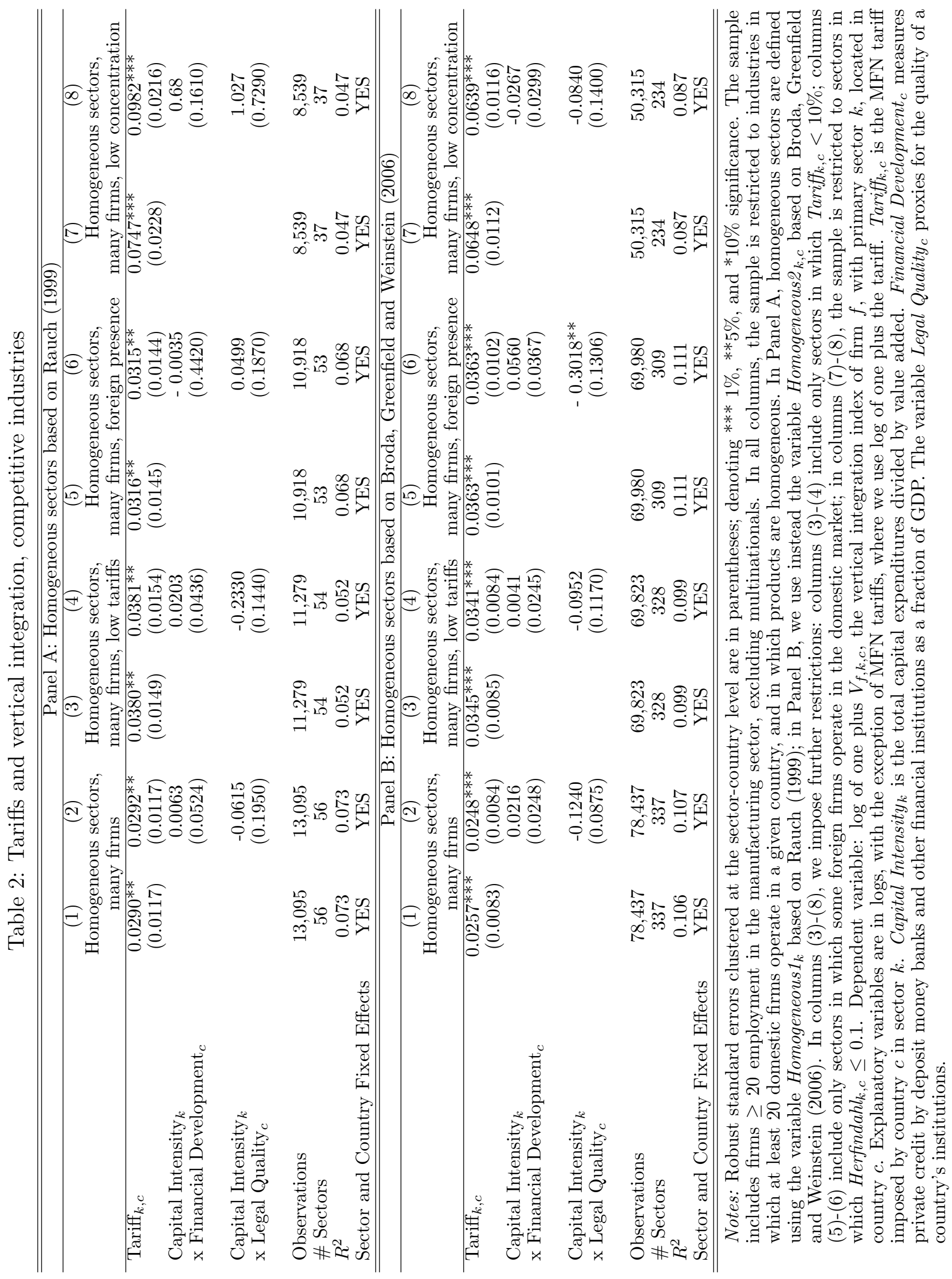




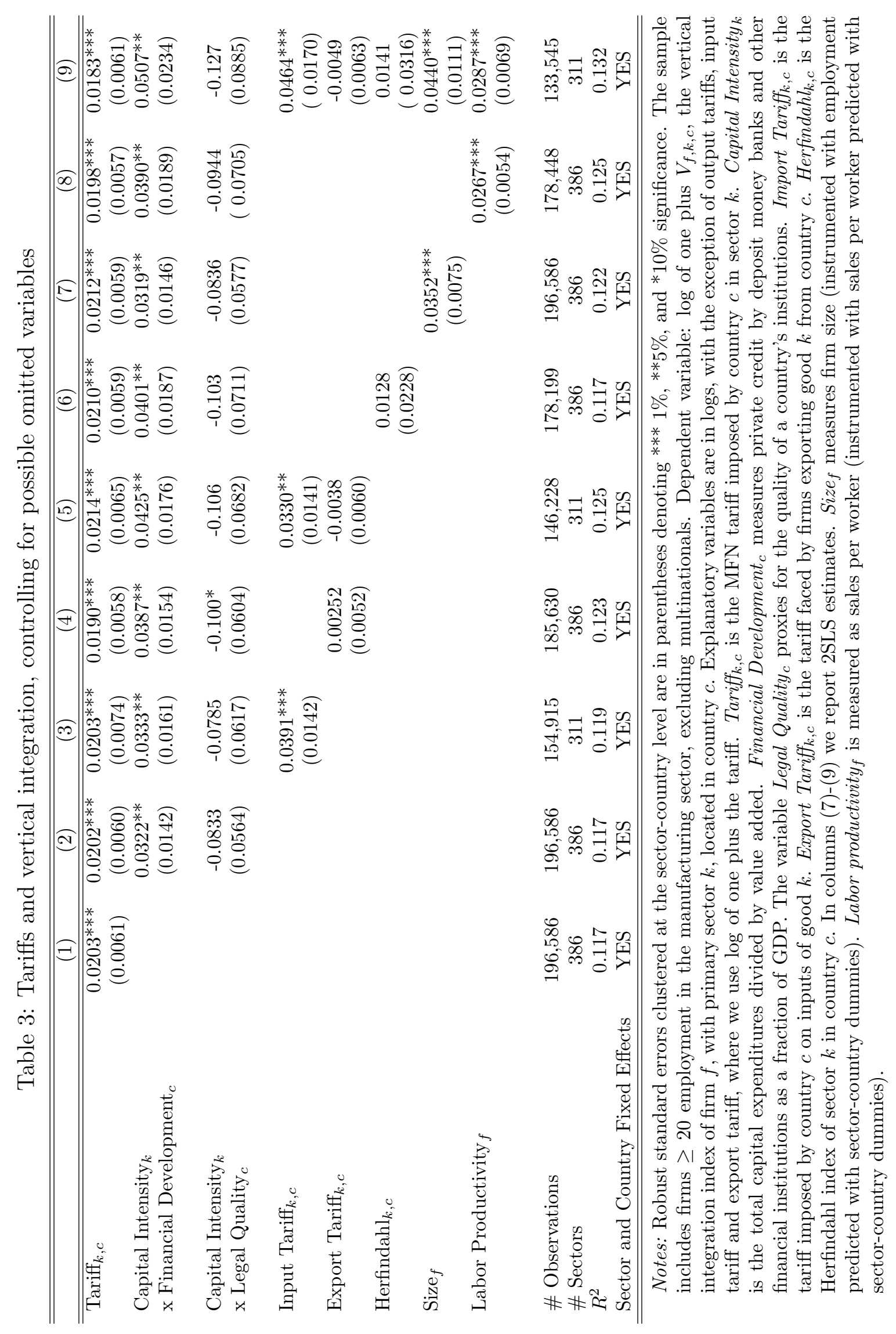




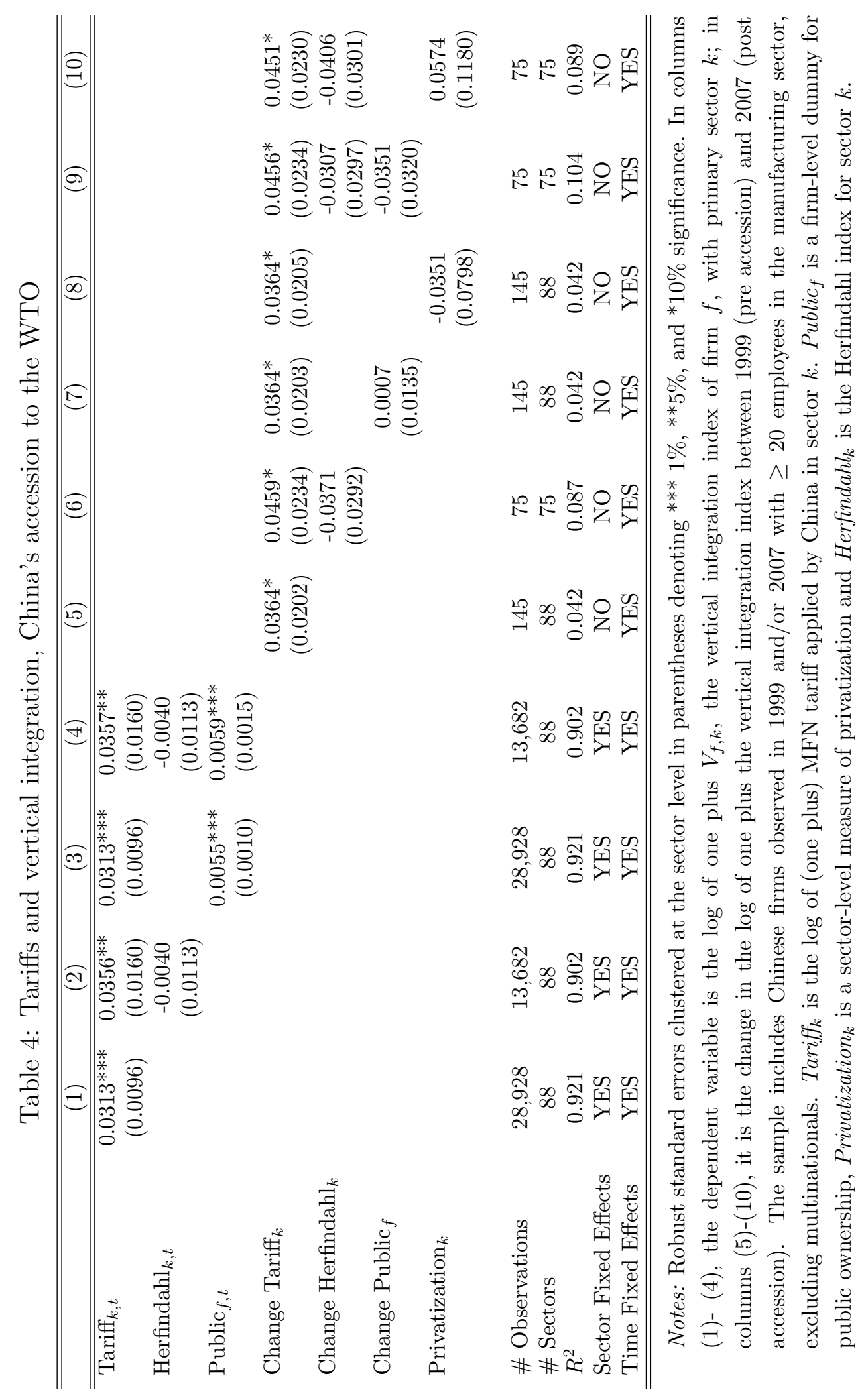


Table 5: Trade policy and organizational convergence

\begin{tabular}{|c|c|c|c|}
\hline \multicolumn{4}{|c|}{ Panel A: Tariff differences } \\
\hline Difference Tariffs $s_{k, c, c^{\prime}}$ & $\begin{array}{c}(1) \\
0.0089 * * * \\
(0.0034)\end{array}$ & $\begin{array}{c}(2) \\
0.0086^{* *} \\
(0.0037)\end{array}$ & \\
\hline $\begin{array}{l}\text { Capital Intensity } k \\
\text { x Difference Financial Development } \\
c, c^{\prime}\end{array}$ & & $\begin{array}{c}0.0020 \\
(0.0066)\end{array}$ & \\
\hline $\begin{array}{l}\text { Capital Intensity }_{k} \\
\text { x Difference Legal Quality } k, c, c^{\prime}\end{array}$ & & $\begin{array}{c}0.0419^{* * *} \\
(0.0062)\end{array}$ & \\
\hline $\begin{array}{l}\text { \# Observations } \\
\# \text { Country pairs } \\
R^{2} \\
\text { Sector and Country-pair Fixed Effects } \\
\end{array}$ & $\begin{array}{c}212,770 \\
80 \\
0.164 \\
\text { YES } \\
\end{array}$ & $\begin{array}{c}171,908 \\
80 \\
0.164 \\
\text { YES } \\
\end{array}$ & \\
\hline \multicolumn{4}{|c|}{ Panel B: Regional Trade Agreements } \\
\hline $\mathrm{RTA}_{c, c^{\prime}}$ & $\begin{array}{c}(1) \\
-0.0921^{* * *} \\
(0.0235)\end{array}$ & $(2)$ & $(3)$ \\
\hline Customs Union $_{c, c^{\prime}}$ & & $\begin{array}{c}-0.185^{* * *} \\
(0.0376)\end{array}$ & $\begin{array}{c}-0.0760^{*} \\
(0.046)\end{array}$ \\
\hline Free Trade Area $_{c, c^{\prime}}$ & & $\begin{array}{l}-0.0404 \\
(0.0266)\end{array}$ & $\begin{array}{c}0.0203 \\
(0.0264)\end{array}$ \\
\hline Distance $_{c, c^{\prime}}$ & & & $\begin{array}{c}0.0188 \\
(0.0146)\end{array}$ \\
\hline Contiguity ${ }_{c, c^{\prime}}$ & & & $\begin{array}{c}-0.196^{* * *} \\
(0.0754)\end{array}$ \\
\hline Common Language $e_{c, c^{\prime}}$ & & & $\begin{array}{c}-0.119^{* * *} \\
(0.0313)\end{array}$ \\
\hline Colonial Relationship $_{c, c^{\prime}}$ & & & $\begin{array}{c}0.0663 \\
(0.0421)\end{array}$ \\
\hline Difference $\mathrm{GDP}_{c, c^{\prime}}$ & & & $\begin{array}{c}0.0389^{* * * *} \\
(0.0087)\end{array}$ \\
\hline \# Observations & 299,649 & 299,649 & 299,649 \\
\hline \# Country pairs & 101 & 101 & 101 \\
\hline$R^{2}$ & 0.109 & 0.109 & 0.111 \\
\hline Sector and Country Fixed Effects & YES & YES & YES \\
\hline
\end{tabular}

Notes: Robust standard errors clustered at the country-pair level in parentheses denoting $* * * 1 \%, * * 5 \%$, and $* 10 \%$ significance. Dependent variable: $\log$ of (one plus) the absolute difference between countries $c$ and $c^{\prime}$ in the estimated vertical integration index of firms with primary sector $k$. The variable Difference Tariffs $s_{k, c, c^{\prime}}$ is the difference between the MFN tariff imposed by country $c$ and $c^{\prime}$ in sector $k$. Capital Intensity $k_{k}$ is the total capital expenditures divided by value added. Difference Financial Development ${ }_{c c^{\prime}}$ measures differences in private credit by deposit money banks and other financial institutions as a fraction of GDP. The variable Difference in Legal Quality $_{c}$ proxies differences in the quality of institutions across between two countries. The variables Contiguityc, ${ }_{c, c^{\prime}}$, Colonial Relationship $p_{c, c^{\prime}}$, Common Language $_{c, c^{\prime}}$ and Difference $G D P_{c, c^{\prime}}$ capture bilateral geographical, cultural and economic linkages. 


\section{Appendix}

Table A-1: Main sample

\begin{tabular}{|c|c|c|c|c|c|c|c|}
\hline WB code & Freq. & Percent & Cum. & WB code & Freq. & Percent & Cum. \\
\hline ALB & 4 & 0.00 & 0.00 & MAR & 603 & 0.31 & 61.52 \\
\hline ARG & 998 & 0.51 & 0.51 & MDG & 18 & 0.01 & 61.53 \\
\hline AUS & 5,079 & 2.58 & 3.09 & MEX & 2,641 & 1.34 & 62.87 \\
\hline AUT & 1,464 & 0.74 & 3.84 & MLI & 13 & 0.01 & 62.88 \\
\hline BEL & 928 & 0.47 & 4.31 & MOZ & 16 & 0.01 & 62.89 \\
\hline BEN & 4 & 0.00 & 4.31 & MUS & 46 & 0.02 & 62.91 \\
\hline BFA & 8 & 0.00 & 4.32 & MWI & 2 & 0.00 & 62.91 \\
\hline BGD & 6 & 0.00 & 4.32 & MYS & 3,101 & 1.58 & 64.49 \\
\hline BGR & 360 & 0.18 & 4.50 & NER & 1 & 0.00 & 64.49 \\
\hline BOL & 55 & 0.03 & 4.53 & NIC & 21 & 0.01 & 64.50 \\
\hline BRA & 5,594 & 2.85 & 7.38 & NLD & 676 & 0.34 & 64.84 \\
\hline CAN & 7,469 & 3.80 & 11.18 & NOR & 847 & 0.43 & 65.27 \\
\hline $\mathrm{CHE}$ & 1,150 & 0.58 & 11.76 & NZL & 959 & 0.49 & 65.76 \\
\hline CHL & 454 & 0.23 & 11.99 & OMN & 67 & 0.03 & 65.80 \\
\hline COL & 550 & 0.28 & 12.27 & PAK & 4 & 0.00 & 65.80 \\
\hline CRI & 176 & 0.09 & 12.36 & PER & 888 & 0.45 & 66.25 \\
\hline CZE & 1,736 & 0.88 & 13.24 & PHL & 351 & 0.18 & 66.43 \\
\hline DEU & 19,302 & 9.82 & 23.06 & PNG & 4 & 0.00 & 66.43 \\
\hline DNK & 425 & 0.22 & 23.28 & POL & 446 & 0.23 & 66.66 \\
\hline ECU & 183 & 0.09 & 23.37 & PRT & 5,433 & 2.76 & 69.42 \\
\hline ESP & 2,322 & 1.18 & 24.55 & PRY & 50 & 0.03 & 69.45 \\
\hline FIN & 448 & 0.23 & 24.78 & ROM & 614 & 0.31 & 69.76 \\
\hline FRA & 8,965 & 4.56 & 29.34 & RWA & 2 & 0.00 & 69.76 \\
\hline GAB & 3 & 0.00 & 29.34 & SAU & 314 & 0.16 & 69.92 \\
\hline GBR & 6,622 & 3.37 & 32.71 & SEN & 47 & 0.02 & 69.94 \\
\hline GHA & 81 & 0.04 & 32.75 & SGP & 790 & 0.40 & 70.35 \\
\hline GRC & 2,231 & 1.13 & 33.89 & SLV & 129 & 0.07 & 70.41 \\
\hline GTM & 93 & 0.05 & 33.93 & SWE & 689 & 0.35 & 70.76 \\
\hline HND & 77 & 0.04 & 33.97 & TGO & 4 & 0.00 & 70.76 \\
\hline HUN & 2,346 & 1.19 & 35.17 & THA & 507 & 0.26 & 71.02 \\
\hline IDN & 233 & 0.12 & 35.29 & TTO & 79 & 0.04 & 71.06 \\
\hline IND & 2,592 & 1.32 & 36.60 & TUN & 991 & 0.50 & 71.57 \\
\hline IRL & 587 & 0.30 & 36.90 & TUR & 2,557 & 1.30 & 72.87 \\
\hline ISR & 1,538 & 0.78 & 37.68 & TZA & 24 & 0.01 & 72.88 \\
\hline ITA & 8,426 & 4.29 & 41.97 & UGA & 37 & 0.02 & 72.90 \\
\hline JAM & 43 & 0.02 & 41.99 & URY & 114 & 0.06 & 72.96 \\
\hline JOR & 148 & 0.08 & 42.07 & USA & 52,917 & 26.92 & 99.87 \\
\hline JPN & 34,441 & 17.52 & 59.59 & VEN & 231 & 0.12 & 99.99 \\
\hline KEN & 134 & 0.07 & 59.66 & $\mathrm{ZAF}$ & 1 & 0.00 & 99.99 \\
\hline \multirow[t]{2}{*}{ KOR } & 3,060 & 1.56 & 61.21 & ZMB & 17 & 0.01 & 100.00 \\
\hline & & & & Total & 196,586 & 100.00 & \\
\hline
\end{tabular}

Notes: Data from 2004 WorldBase data, Dun \& Bradstreet. Sample includes all firms in manufacturing sectors that have at least 20 employees and are located in WTO member countries, excluding multinationals. 
Table A-2: Summary statistics

\begin{tabular}{|c|c|c|c|c|}
\hline Sample & & & & $\mathrm{N}$ \\
\hline Plants & & & & 225,212 \\
\hline Connected plants & & & & 29,214 \\
\hline Multi-plant firms & & & & 6,830 \\
\hline Single-plant firms & & & & 189,756 \\
\hline Firms & & & & 196,586 \\
\hline 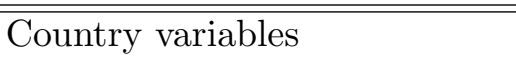 & Median & Mean & Std. Dev. & $\mathrm{N}$ \\
\hline Vertical Integration Index $f$ & 0.044 & 0.063 & 0.063 & 196,586 \\
\hline $\operatorname{Size}_{f}$ & 38.000 & 98.936 & 472.395 & 196,586 \\
\hline Labor productivity $f$ & 11.506 & 11.446 & 1.082 & 178,448 \\
\hline Domestic $_{f}$ & 0 & 0.233 & 0.423 & 196,586 \\
\hline Import-competing $_{k, c}$ & 0.702 & 0.705 & 0.571 & 196,586 \\
\hline $\operatorname{Tariff}_{k, c}$ & 2.480 & 4.849 & 7.253 & 196,586 \\
\hline Input Tariff $_{k, c}$ & 2.546 & 3.994 & 4.954 & 154,915 \\
\hline Export Tariff $_{k, c}$ & 5.654 & 6.611 & 5.039 & 185,630 \\
\hline MFN Share $_{k, c}$ & 0.564 & 0.545 & 0.351 & 196,586 \\
\hline Herfindahl $_{k, c}$ & 0.053 & 0.132 & 0.188 & 178,199 \\
\hline Homogeneous $1_{k}$ & 0 & 0.081 & 0.273 & 196,586 \\
\hline Homogeneous $2_{k, c}$ & 0 & 0.491 & 0.499 & 173,587 \\
\hline Capital Intensity $_{k}$ & -2.857 & -2.902 & 0.458 & 387 \\
\hline Financial Development $_{c}$ & 0.332 & 0.554 & 0.479 & 80 \\
\hline Legal Quality $_{c}$ & 0.545 & 0.583 & 0.209 & 80 \\
\hline Country-pair variables & Median & Mean & Std. Dev. & $\mathrm{N}$ \\
\hline Difference Ver. Int. Index $k, c, c^{\prime}$ & -1.593 & -1.707 & 1.614 & 299,649 \\
\hline Regional Trade Agreement $c, c^{\prime}$ & 0.000 & 0.263 & 0.440 & 299,649 \\
\hline Free Trade Agreement ${ }_{c, c^{\prime}}$ & 0.000 & 0.148 & 0.355 & 299,649 \\
\hline Customs Union $_{c, c^{\prime}}$ & 0.000 & 0.115 & 0.319 & 299,649 \\
\hline Distance $_{c, c^{\prime}}$ & 9.017 & 8.629 & 0.965 & 299,649 \\
\hline Contiguity $_{c, c^{\prime}}$ & 0.000 & 0.041 & 0.139 & 299,649 \\
\hline Colonial Relationship $p_{c, c^{\prime}}$ & 0.000 & 0.020 & 0.178 & 299,649 \\
\hline Common Language $_{c, c^{\prime}}$ & 0.000 & 0.122 & 0.328 & 299,649 \\
\hline Difference $\mathrm{GDP}_{c, c^{\prime}}$ & 0.450 & 0.201 & 1.812 & 299,649 \\
\hline
\end{tabular}

Sources: Vertical Integration Index ${ }_{f}$, Size $_{f}$, Labor Productivity, , Domestic $f_{f}$ and Herfindahl $k_{, c}$ constructed using plant-level data from 2004 WorldBase, Dun \& Bradstreet. Sample includes manufacturing firms with at least 20 employees and excludes multinationals. Tariffk,c from the World Integrated Trade Solution (WITS); Input Tariff $_{k, c}$, Export Tariffk,c , and MFN Share $k_{, c}$ constructed using data from WITS and the UN Comtrade database.

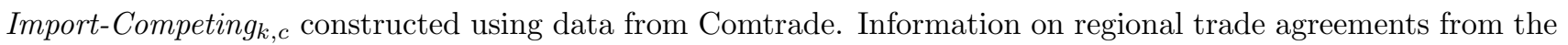
WTO. Homogeneous $1_{k}$ from Rauch (1999), Homogeneous $2_{k, c}$ constructed using data from Broda, Greenfield and Weinstein (2006). Capital Intensity from NBER-CES manufacturing industry database. Financial Development $t_{c}$ from Beck, Demigurc-Kunt and Levine (2006). Legal Qualityc from Kaufmann, Kraay, and Mastruzzi (2004). $G D P_{c}$ from the World Bank. Contiguity $c_{c, c^{\prime}}$, Colonial Relationship $c_{c, c^{\prime}}$, and Common Language $e_{c, c^{\prime}}$ from CEPII.

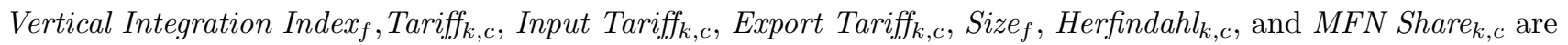
in levels; all other variables (with the exception of indicator variables) are in logs. 
Table A-3: Vertical integration by 2-digit SIC industry

\begin{tabular}{lcc}
\hline \hline Industry & SIC & VI index \\
\hline \hline TEXTILES & 22 & 0.115 \\
APPAREL & 23 & 0.111 \\
CHEMICALS & 28 & 0.098 \\
PRIMARY METAL PRODUCTS & 33 & 0.091 \\
ELECTRICAL MACHINERY & 36 & 0.089 \\
TRANSPORTATION EQUIPMENT & 37 & 0.067 \\
PETROLEUM REFINING & 29 & 0.062 \\
LEATHER & 31 & 0.062 \\
RUBBER AND PLASTICS & 30 & 0.060 \\
MACHINERY, EXCEPT ELECTRICAL & 35 & 0.060 \\
MANUFACTURING NEC & 39 & 0.059 \\
LUMBER AND WOOD PRODUCTS & 24 & 0.059 \\
FOOD AND KINDRED PRODUCTS & 20 & 0.056 \\
TOBACCO MANUFACTURES & 21 & 0.053 \\
STONE, CLAY, GLASS, \& CONCRETE & 32 & 0.049 \\
FABRICATED METAL PRODUCTS & 34 & 0.039 \\
PRINTING AND PUBLISHING & 27 & 0.039 \\
SCIENTIFIC INSTRUMENTS & 38 & 0.036 \\
PAPER AND ALLIED PRODUCTS & 26 & 0.034 \\
FURNITURE AND FIXTURES & 25 & 0.022 \\
\hline \hline
\end{tabular}

Notes: Data from 2004 WorldBase data, Dun \& Bradstreet. Sample includes firms $\geq 20$ employment in the manufacturing sector, excluding multinationals. 


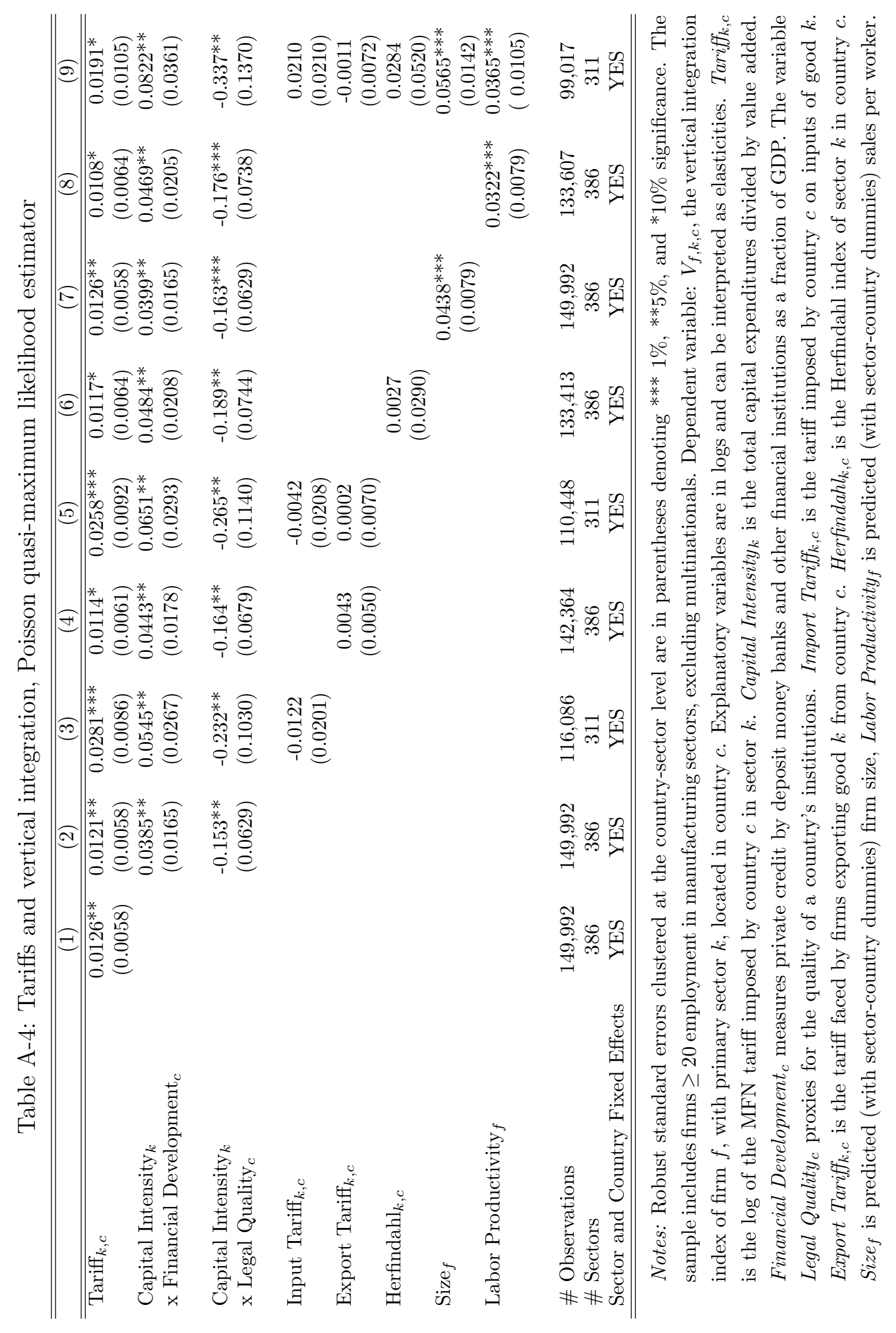

